\title{
Fine-scale vertical structure of sound-scattering layers over an east border upwelling system and its relationship to pelagic habitat characteristics
}

\author{
Ndague Diogoul $^{1,2,6}$, Patrice Brehmer ${ }^{2,3,6}$, Yannick Perrot ${ }^{3}$, Maik Tiedemann ${ }^{4}$, Abou Thiam ${ }^{1}$, \\ Salaheddine El Ayoubi ${ }^{5}$, Anne Mouget ${ }^{3}$, Chloé Migayrou ${ }^{3}$, Oumar Sadio ${ }^{2}$, and Abdoulaye Sarré \\ ${ }^{1}$ University Cheikh Anta Diop UCAD, Institute of Environmental Science (ISE), BP 5005, Dakar, Senegal \\ ${ }^{2}$ IRD, Univ. Brest, CNRS, Ifremer, LEMAR, Campus UCAD-IRD de Hann, Dakar, Senegal \\ ${ }^{3}$ IRD, Univ. Brest, CNRS, Ifremer, LEMAR, DR Ouest, Plouzané, France \\ ${ }^{4}$ Institute of Marine Research IMR, Pelagic Fish, P.O. Box 1870 Nordnes, 5817 Bergen, Norway \\ ${ }^{5}$ Institut National de Recherche Halieutique INRH, Agadir, Morocco \\ ${ }^{6}$ Institut Sénégalais de Recherches agricoles ISRA, Centre de Recherches Océanographiques de Dakar-Thiaroye (CRODT), \\ BP 2221 Dakar, Senegal
}

Correspondence: Ndague Diogoul (diogoulndague@yahoo.fr)

Received: 12 March 2019 - Discussion started: 8 April 2019

Revised: 20 November 2019 - Accepted: 25 November 2019 - Published: 13 January 2020

\begin{abstract}
Understanding the relationship between soundscattering layers (SSLs) and pelagic habitat characteristics is a substantial step to apprehend ecosystem dynamics. SSLs are detected on echo sounders representing aggregated marine pelagic organisms. In this study, SSL characteristics of zooplankton and micronekton were identified during an upwelling event in two contrasting areas of the Senegalese continental shelf. Here a cold upwelling-influenced inshore area was sharply separated by a strong thermal boundary from a deeper, warmer, stratified offshore area. Mean SSL thickness and SSL vertical depth increased with the shelf depth. The thickest and deepest SSLs were observed in the offshore part of the shelf. Hence, zooplankton and micronekton seem to occur more frequently in stratified water conditions rather than in fresh upwelled water. Diel vertical and horizontal migrations of SSLs were observed in the study area. Diel period and physicochemical water characteristics influenced SSL depth and SSL thickness. Although chlorophyll- $a$ concentration insignificantly affected SSL characteristics, the peak of chlorophyll $a$ was always located above or in the middle of the SSLs, regularly matching with the peak of SSL biomass. Such observations indicate trophic relationships, suggesting SSLs to be mainly composed of phytoplanktivorous zooplankton and micronekton. Despite local hypoxia, below $30 \mathrm{~m}$ depth, distribution patterns of SSLs indicate no
\end{abstract}

vertical migration boundary. The results increase the understanding of the spatial organization of mid-trophic species and migration patterns of zooplankton and micronekton, and they will also improve dispersal models for organisms in upwelling regions.

\section{Introduction}

Aggregations of marine pelagic organisms in ocean water can be observed acoustically as sound-scattering layers (SSLs) (Evans and Hopkins, 1981; Cascão et al., 2017). The SSLs represent a concentrated layer of marine organisms such as zooplankton aggregates and nekton that occur at specific depths (Benoit-Bird and Au, 2004). Nevertheless, the SSL is not a biological classification, and animals making up SSLs include various species, with correspondingly different biological, physiological, and ecological needs. The SSLs are dynamic, active, and have a particular behavior as a function of their community structure, causing changes in their vertical distribution, size, and shape over time and space (GómezGutiérrez et al., 1999). Zooplanktonic and micronektonic components are fundamental to ecosystem functioning, par- 
ticularly in productive upwelling areas (e.g., off the south coast of Senegal).

Zooplanktonic and micronektonic species provide the main trophic link between primary producers and higher trophic levels. A large amount of energy passes through zooplankton and micronekton (Steele et al., 2007). Knowledge of the vertical structure of SSLs allows us to understand their role in ecosystems, information that can be used to monitor major environmental change and variability. Most zooplankton and micronektonic taxa undergo diel vertical migration (DVM), meaning that they reside in deep waters during the day and migrate toward the surface at night to feed (Bianchi et al., 2013; Lehodey et al., 2015). DVM behaviors are influenced by environmental cues (e.g., light, nutrients, and temperature) and predator-prey interactions (Clark and Levy, 1988; Lampert, 1989). Thus, DVMs represent an essential biological process in the ocean, one that also regulates the biological carbon pump (Hidaka et al., 2001). Zooplankton and micronekton are also known to undergo diel horizontal migration (DHM), moving them to within $1 \mathrm{~km}$ of the shoreline each night into shallower waters (Benoit-Bird et al., 2001). DHM, like DVM, which often occur concurrently, helps organisms to find food and avoid predators (White, 1998).

The distribution of SSLs is influenced by a variety of environmental factors (Aoki and Inagaki, 1992; Baussant et al., 1992; Dekshenieks et al., 2001; Marchal et al., 1993). Changes in the structure and density of SSLs is associated with frontal zones (Aoki and Inagaki, 1992; Baussant et al., 1992; Boersch-Supan et al., 2017; Coyle and Cooney, 1993). Oceanic fronts are relatively narrow zones of enhanced horizontal gradients of physical, chemical, and biological properties (temperature, salinity, nutrients, plankton communities, etc.) that separate broader areas of different vertical structure (stratification) (Belkin et al., 2009). Upwelling fronts occur in many well-studied systems, including the upwelling off southern Senegal, south of Cap-Vert peninsula known as the "Petite Côte" (14.6-13.5 $\mathrm{N}, 16.9-$ $\left.17.6^{\circ} \mathrm{W}\right)$. Senegalese coasts are characterized by a seasonal upwelling (in winter and late spring), mainly driven by wind variability, topography, and density stratification (Estrade et al., 2008). During the upwelling season, northerly trade winds induce a strong upwelling core south of Dakar (Ndoye et al., 2014; Roy, 1998). The upwelling core is located over the shelf, and SST (sea surface temperature) is lowest on the coastal side of the shelf break, increasing in both offshore and coastal directions. Local bottom relief combined with the wind-induced upwelling establishes a typical upwelling that appears as a cold-water tongue. This cold-water tongue separates the nutrient-poor warm offshore cell with a cold nutrient-rich coastal cell functioning as a retention zone (Roy, 1998; Tiedemann and Brehmer, 2017). The Petite Côte in the Senegalese coastal shelf is a nursery area for fish and is the main area in which juveniles of numerous species, particularly small pelagic species, concentrate (Diankha et al., 2018; Thiaw et al., 2017). This area is also known to be rich in zooplankton and micronekton. Many zooplankton groups are encountered over the Senegalese coastal shelf: Copepods, amphipods, annelids, appendicularians, chaetognaths, cirrhipeds, cladocerans, Decapoda, echinoderms, euphausiids, gasteropods, jellyfish, Mysidacea, ostracods, pelagic foraminifera, Protozoa, pteropods, and Spumellaria. Copepod is the most dominant group with a total abundance ranging from $50 \%$ to $90 \%$ (Anonymous, 2013; Ndour et al., 2018; Touré, 1971). Previous studies (Ndour et al., 2018; Tiedemann and Brehmer, 2017) on ichthyoplankton showed that Sparidae $(\sim 50 \%)$ was predominant, followed by fewer Engraulidae $(\sim 8 \%)$ and Soleidae $(\sim 7 \%)$, while smaller proportions of Clupeidae and Carangidae ( $\sim 4 \%$ each) as well as Myctophidae and Sciaenidae $(\sim 2 \%$ each) were found. Physical variability in the Senegalese coastal shelf (Capet et al., 2016; Ndoye et al., 2017) can impact marine pelagic organisms at the individual and community level (Urmy and Horne, 2016). Such an impact can be direct via advection or indirect via phytoplankton production fertilized by upwelled nutrients. Indeed, changes in physicochemical water properties and biological activities induced by upwelling plays a structuring role on the distribution of SSLs. SSL position is often reported below the thermocline, suggesting that temperature controls the SSL's vertical distribution (Aoki and Inagaki, 1992; Baussant et al., 1992; BoerschSupan et al., 2017; Marchal et al., 1993). Bottom depth has been identified as an additional factor structuring the vertical distribution of SSLs (Gausset and Turrel, 2001). For example, the thickness and depth of an SSL on continental shelves tend to increase with an increase in water depth (Torgersen et al., 1997), similar to patterns observed in the deep sea (Berge et al., 2014; Boersch-Supan et al., 2017). In deepsea areas and over shelves, the maximum density of SSLs are often correlated with maximum chlorophyll- $a$ concentrations (Berge et al., 2014; Dekshenieks et al., 2001; Holliday et al., 2010). Dissolved oxygen concentrations (above $1 \mathrm{~mL} \mathrm{~L}^{-1}$, i.e., $44.661 \mathrm{mmol} \mathrm{m}^{-3}$ ) can also predict the lower boundary of SSL density, e.g., in eastern boundary upwelling systems (EBUSs), like the Peruvian coastal upwelling system (Bertrand et al., 2010) and the California coastal upwelling system (Netburn and Koslow, 2015).

In this study, we use acoustic tools (Simmonds and MacLennan, 2005a) to examine the fine-scale vertical structure of SSLs (i.e., their depth in the water column, thickness, and density) (Bertrand et al., 2013; Perrot et al., 2018). We use fine spatiotemporal resolution of acoustic data to investigate how the pelagic environment influences SSLs in the EBUS off Senegal during an upwelling event. Our objective was to model variations in SSLs structure relative to physicochemical characteristics of water masses and their locations on the shelf. 


\section{Materials and methods}

\subsection{SSLs acoustics sensing and environmental data}

We performed a hydroacoustic survey along the "Petite Côte", south of Cap-Vert peninsula off Senegal (14.6$\left.13.5^{\circ} \mathrm{N}, 16.9-17.6^{\circ} \mathrm{W}\right)$. The survey was conducted with the research vessel Antea of the French National Research Institute of Sustainable Development (IRD France) during the upwelling season from 6 to 18 March 2013. The Petite Côte is a nursery area for fish and is the main area in which juveniles of numerous species (particularly small pelagic species) concentrate (Diankha et al., 2018; Thiaw et al., 2017). Strong upwelling occurs during spring, which contributes to high primary productivity, thus providing an ideal nursery area for commercially important fish species (Tiedemann and Brehmer, 2017).

We collected hydroacoustic data along three transects (T1 (North), T2 (intermediary), and T3 (south)) in 18 nautical miles (nmi) perpendicular to the coast (Fig. 1). Hydroacoustic data were continuously recorded (day and night) using a Simrad EK60 echo sounder $(38,70,120$, and $200 \mathrm{kHz})$, set at $20 \log R$ time-varied gain function (where $R$ is the range in meters) and using a pulse length of $1.0 \mathrm{~ms}$. In this study, we used the acoustic monofrequency approach (using $38 \mathrm{kHz}$, one of the most current frequencies used in fisheries surveys) to study the spatiotemporal SSL structure. The $38 \mathrm{kHz}$ frequency offers the advantages of depth penetration, covering the whole vertical range of SSLs. The multifrequency echogram was used to identify the main scatterers of SSLs and to justify the SSLs extraction threshold (see below). Transducers were calibrated following the procedures recommended in Foote et al. (1987). Considering the aft draught of the vessel, the acoustic near field, and the presence of acoustic parasites (including air bubbles) in the upper part of the water column, we have applied an offset of $10 \mathrm{~m}$ (acoustic data above $10 \mathrm{~m}$ have been deleted). Echoes along the three transects were integrated at a spatial resolution of $0.1 \mathrm{nmi} \times 1 \mathrm{~m}$ depth. We estimated the SSL acoustic density by calculating the nautical area scattering coefficient (NASC or $s_{\mathrm{A}}$ ), which represents the relative biomass of acoustic targets. We assumed that the composition of the scattering layers and the resulting scattering properties of organisms in the SSLs are homogeneous within each layer we identified (sensu MacLennan et al., 2002). We analyzed integrated echoes using the in-house tool "Matecho" (Perrot et al., 2018). Matecho is an integrative processing software that allows us to manually correct echograms (e.g., by correcting bottom depths, removing empty pings, removing echogram interferences, and reducing background noise). For echo-integration accuracy, Matecho computes a quality factor (QC) (Fig. S1 in the Supplement) for each echo-integration cell, which is the number of integrated samples divided by the total number of samples in one echo-integration cell. After each echogram cor-

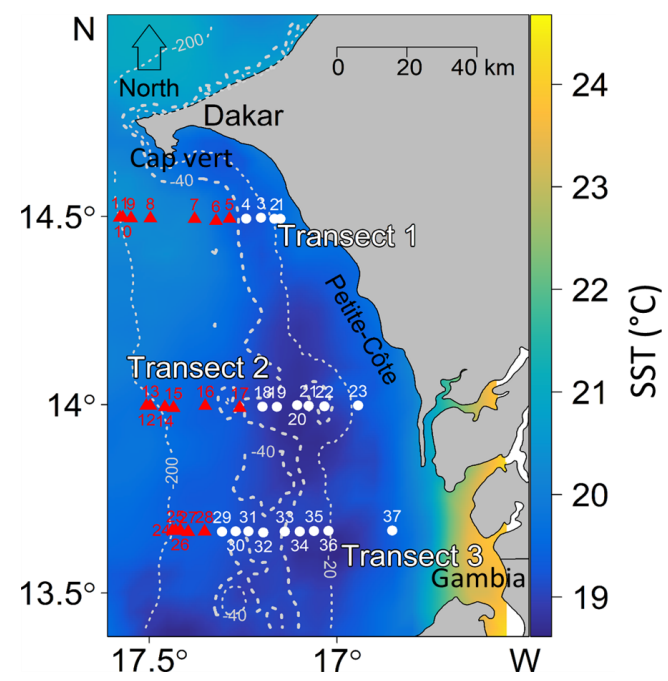

Figure 1. Location of the survey area off the southern Senegalese (West African) coast. The hydroacoustic survey was conducted with FRV Antea (IRD) from Dakar (Cap-Vert peninsula) to the northern border of Gambia. CTD probes collected data at stations along three transects perpendicular to the coast (T1 to T3). Sea surface temperatures (SST, ${ }^{\circ} \mathrm{C}$ ) were averaged over the $3 \mathrm{~d}$ of CTD sampling from the 6 to 8 March 2013. Stations of Group 1 (white circles) were located in the inshore zone, whereas stations of Group 2 (red triangles) were situated further offshore. The dashed white lines represent bathymetry (in meters).

rection, we extracted the SSLs that were below the mean acoustic volume backscattering strength $\left(S_{\mathrm{v}}\right.$ in $\left.\mathrm{dB}\right)$ threshold of $-75 \mathrm{~dB}$ (i.e., values below $-75 \mathrm{~dB}$ were excluded from the analysis). Cascão et al. (2017) and Saunders et al. (2013) excluded marine pelagic organisms that backscattered at $-70 \mathrm{~dB}$, a threshold based on the aggregative behavior of marine pelagic organisms. The SSL extraction method is based on a threshold of $-75 \mathrm{~dB}$ and a MATLAB algorithm used in Matecho named "contourf.m" (https: //ch.mathworks.com/help/matlab/ref/contourf.html, last access: 12 January 2019), which appear relevant to extract the main SSL at $38 \mathrm{kHz}$ (Fig. S2). This process performs a segmentation of the echo integration from the given threshold on echo levels to extract (by calculation of isolines according to the selected $S_{\mathrm{v}}$ threshold) the attached echo groups that formed the SSLs and their associated contours. Based on this contour, a set of descriptors are estimated, e.g., up and down depths of SSL and thickness. In our study, the backscattering was due to zooplankton and micronekton, as well as small pelagic fish. The inshore area is known to be rich in copepod and fish larva (Ndour et al., 2018; Tiedemann and Brehmer, 2017); however, a low sample number was collected in the coastal inshore water due to safety reasons, i.e., the research vessel investigated areas of $>20 \mathrm{~m}$ bottom depth.

We collected hydrographic data using a calibrated SeaBird SBE 19plus conductivity, temperature, and depth (CTD) probe. The CTD specifications for temperature were 
$\pm 5.10^{-3 \circ} \mathrm{C}$ accuracy and $1.10^{-4}{ }^{\circ} \mathrm{C}$ precision; for conductivity, they were $\pm 5.10^{-4} \mathrm{~S} \mathrm{~m}^{-1}$ accuracy and $5.10^{-5} \mathrm{~S} \mathrm{~m}^{-1}$ precision; for pressure, they were $\pm 0.1 \%$ of full-scale range accuracy and $2.10^{-3} \%$ precision of full-scale range precision. The CTD was equipped with sensors for fluorescence $\left( \pm 2.10^{-3} \mu g \mathrm{~L}^{-1}\right.$ accuracy, and $\pm 2.10^{-4} \mu \mathrm{g} \mathrm{L}^{-1}$ precision) (a measure of chlorophyll- $a$ concentration, a proxy for phytoplankton biomass), and dissolved oxygen sensor (DO, mmol m $\mathrm{m}^{-3}$, Sea-Bird SBE 43, $2 \%$ saturation for accuracy and $0.2 \%$ saturation for precision). The CTD has been calibrated before the survey. During the survey, data delivered by the SBE 43 for DO have been corrected by Winkler titrations. From 6 to 8 March 2013, we conducted CTD casts along three transects at 36 stations. At each station, sensors measured water temperature $\left({ }^{\circ} \mathrm{C}\right)$, depth $(\mathrm{m})$, fluorescence $\left(\mu \mathrm{g} \mathrm{L}^{-1}\right)$, water density (here sigma-theta, $\mathrm{kg} \mathrm{m}^{-3}$ ), and DO. Global High Resolution Sea Surface Temperature (GHRSST) data were extracted from daily outputs by the Regional Ocean Modeling System group at NASA's Jet Propulsion Laboratory (JPL OurOcean Project, 2010). Daily SST data (GHRSST Level 4 G1SST Global Foundation Sea Surface Temperature Analysis) were averaged for the $3 \mathrm{~d}$ of surveying using SeaDAS software version 7.2 (https://seadas. gsfc.nasa.gov/, last access: 10 November 2018) and interpolated on maps using R software (R Core Team, 2016). Cubic spline interpolations of gridded data were used within the $\mathrm{R}$ package Akima (Akima et al., 2016).

\subsection{Data analysis}

After extracting SSLs with Matecho, we developed an ad hoc MATLAB extension of Matecho named "Layer" (S1 in the Supplement). We obtained SSL thickness, minimum and maximum SSL depths ( $D_{\min }$ and $D_{\max }$, respectively), and an echo-integrated echogram from Matecho output files to provide it to another MATLAB program "ComparEchoProfil" (S2). ComparEchoProfil allows the user to fit in time and depth echo-integrated echograms to the associated CTD vertical profiles. We used the equation below to calculate thickness:

Thickness $=D_{\max }-D_{\min }$

Mean nautical area backscattering coefficient $\left(s_{\mathrm{A}}\right.$, NASC) and mean acoustic volume backscattering strength $\left(S_{\mathrm{V}}\right.$ in $\left.\mathrm{dB}\right)$ profiles were based on the average of three ESUs (small-scale elementary sampling units): the ESU nearest to the CTD position $\left(\mathrm{ESU}_{\mathrm{ctd}}\right)$ as well as previous and following in correspondence with CTD depths $\left(d_{n}\right)$

$$
\begin{aligned}
& \overline{s_{\mathrm{A}}\left(d_{n}\right)}=\sum_{i=\mathrm{ESU}_{\mathrm{ctd}}-1}^{i=\mathrm{ESU}_{\mathrm{ctd}}+1} s_{\mathrm{A}}\left(i, d_{n}\right) / 3, \\
& \overline{S_{\mathrm{v}}\left(d_{n}\right)}=10 \times \log _{10}\left(\sum_{i=\mathrm{ESU}_{\mathrm{ctd}}-1}^{i=\mathrm{ESU}_{\mathrm{ctd}}+1} 10^{\left(S_{\mathrm{v}}\left(i, d_{n}\right) / 10\right)} / 3\right) .
\end{aligned}
$$

The ComparEchoProfil displayed the profile for $S_{\mathrm{v}}$ in $\mathrm{dB}$ over an ESU of $0.1 \mathrm{nmi}$ around each CTD station. The program also allowed us to display acoustic profiles for physicochemical parameters (temperature, CHL (chlorophyll), density, and DO) associated with $S_{\mathrm{V}}$ profiles (Fig. 2). The output included meta-information (station ID, station date, station time, latitude and longitude, diel phase (day, night), and bottom depth), all of which we associated with SSL descriptors (SSL thickness, maximum SSL depth, $S_{\mathrm{v}}$, and $s_{\mathrm{A}}$ ) based on classic fish school descriptors (Brehmer et al., 2007, 2019) and physicochemical parameters associated with each SSL.

We applied hierarchical cluster analyses (HCAs) to discriminate between water masses of inshore and offshore stations over the continental shelf based on CTD data collected at $10 \mathrm{~m}$ depth. HCA was based on Euclidean distance and Ward's aggregation method (Ward, 1963). We used principal component analysis (PCA) (Chessel et al., 2013) on the same dataset to determine similarities between CTD stations relative to environmental parameters. Physicochemical parameters were standardized a priori because they were measured with different metrics.

Inshore-offshore variability of morphometric (thickness, depth) and acoustic characteristics $\left(s_{\mathrm{A}}\right)$ of the SSLs are investigated in the discriminated groups considering bottom depth and diel period. Diel transition periods are removed from analyses to avoid SSL density change biases due to diel vertical migrations. Transition periods are defined using sun altitude, i.e., around sunset and sunrise corresponding to a sun altitude between $\pm 18^{\circ}$ (Lehodey et al., 2015). Morphometric and acoustic characteristics of the SSLs are also compared between the inshore area versus offshore area and between day and night using Student's $t$ test whose application conditions have been verified (normal distribution and variance equality).

Echogram vs. profile coupling figures (Fig. 2) resulting from the ComparEchoProfil were analyzed to determine the relation between environmental parameters and SSLs. ANCOVA tests (analysis of covariance) (Wilcox, 2017) were implemented for SSL characteristics (thickness, depth, and density) in each discriminated area (inshore and offshore). These models were set to predict each descriptor, i.e., thickness, depth, and $s_{\mathrm{A}}$ as a function of temperature, density, DO, CHL, local depth, and diel period. The ANCOVA models were developed on averaged data over station. The selection of the best models was performed using stepwise procedures. Stepwise selection was based on minimizing the Akaike information criterion (AIC) (Akaike, 1974). The relative importance of each variable in total deviance explained was determined from the "relaimpo" $\mathrm{R}$ package (Tonidandel and LeBreton, 2011). Validity assumptions of the models were then assessed by checking for normality of distributed errors and homogeneity of residuals (Figs. S3 to S5). For the ANCOVA, SSL density $\left(s_{\mathrm{A}}\right)$ was $\log _{10}$ transformed for normality assumption. For all statistical tests, the significance threshold used was 0.05 . 
(a)
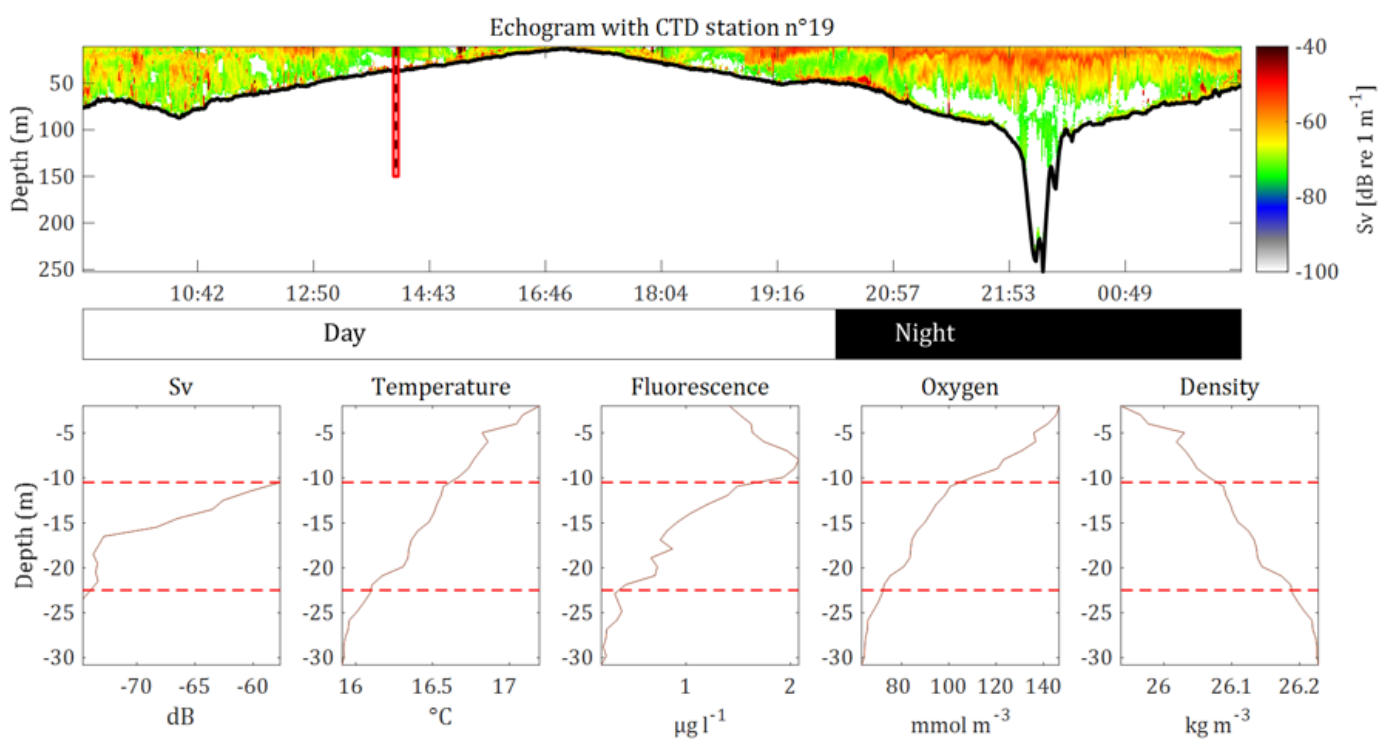

(b)
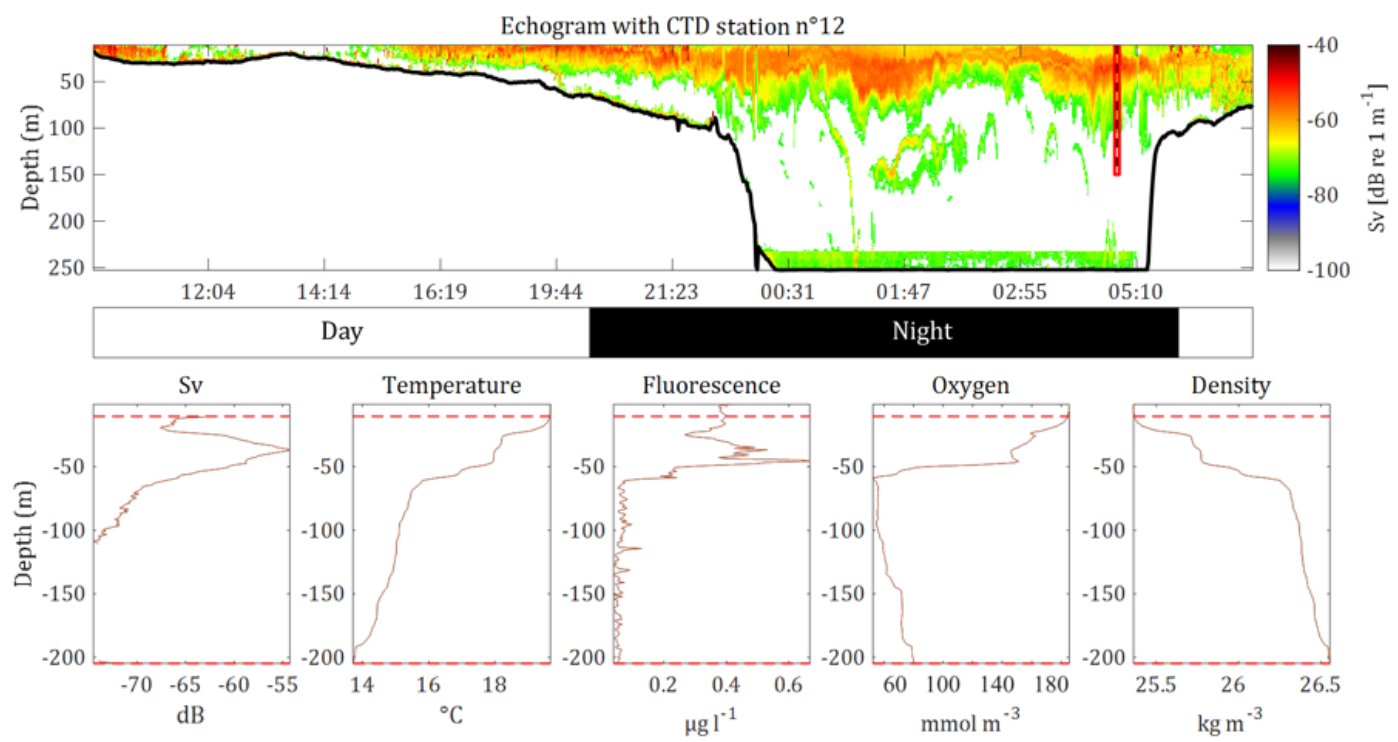

Figure 2. Echograms and associated vertical acoustic profiles as well as physicochemical parameters (CTD data) for two example stations: (a) station 19 in the inshore area and (b) station 12 in the offshore area. For both (a) and (b), top panels are echogram data collected along the transect, i.e., $1000 \mathrm{ESU}$ (elementary sampling unit) of $0.1 \mathrm{nmi}$, whereas the bottom panels depict acoustic and environmental data (depicted by the vertical red line in top panels). Environmental data for the sound-scattering layer (SSL) were collected at the stations at the locations depicted by dotted vertical lines. Data represent mean conditions for the station collected within an area of $0.1 \mathrm{nmi}$ around the station: acoustic volume backscattering strength $\left(S_{\mathrm{V}}\right)$ SSL, temperature profile SSL, CHL profile SSL, oxygen profile SSL, and density profile SSL. The horizontal dashed lines in all profiles represent the SSL thickness, i.e., the upper and lower SSL limits.

We used R software (R Core Team, 2016) for statistical analyses and to map data. We used the R package "Cluster" (Maechler et al., 2014) for HCA of CTD data, the R package "maps" (Brownrigg, 2017) to map stations, the package "ade4" (Chessel et al., 2013) to run a PCA, and the package "oce" (Kelley, 2015) to display vertical section plots of physicochemical parameters.

\section{Results}

\subsection{Characterization of two water masses over the shelf}

The HCA differentiated two groups of stations (Fig. 3a): Group 1 (G1) stations ( $n=18$ ) comprised four stations along transect $\mathrm{T} 1$, six stations along transect $\mathrm{T} 2$, and eight stations along transect T3. The stations of G1 were located closest to 


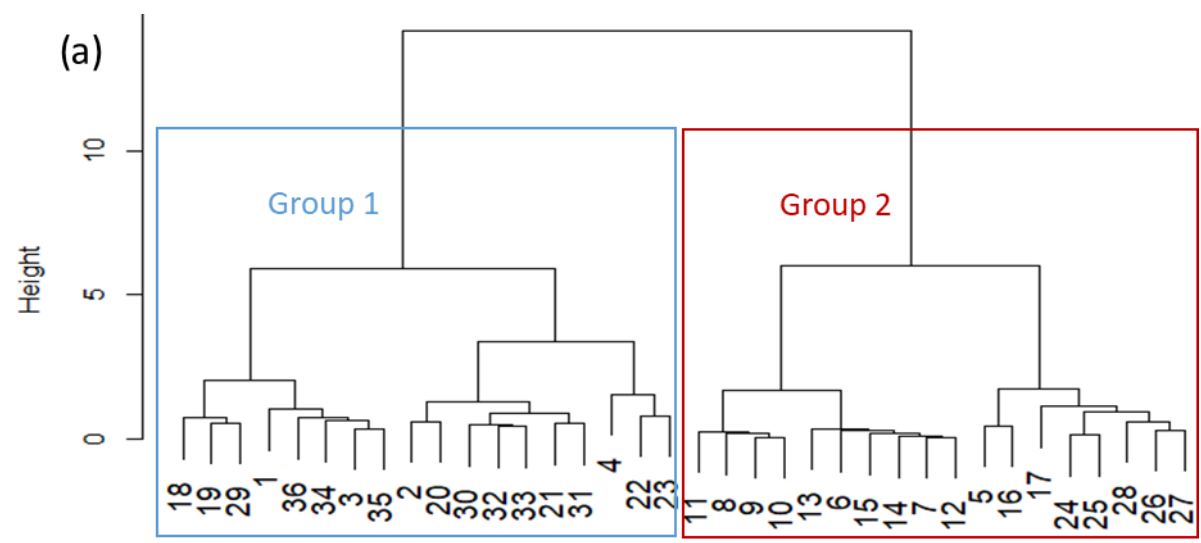

(b)

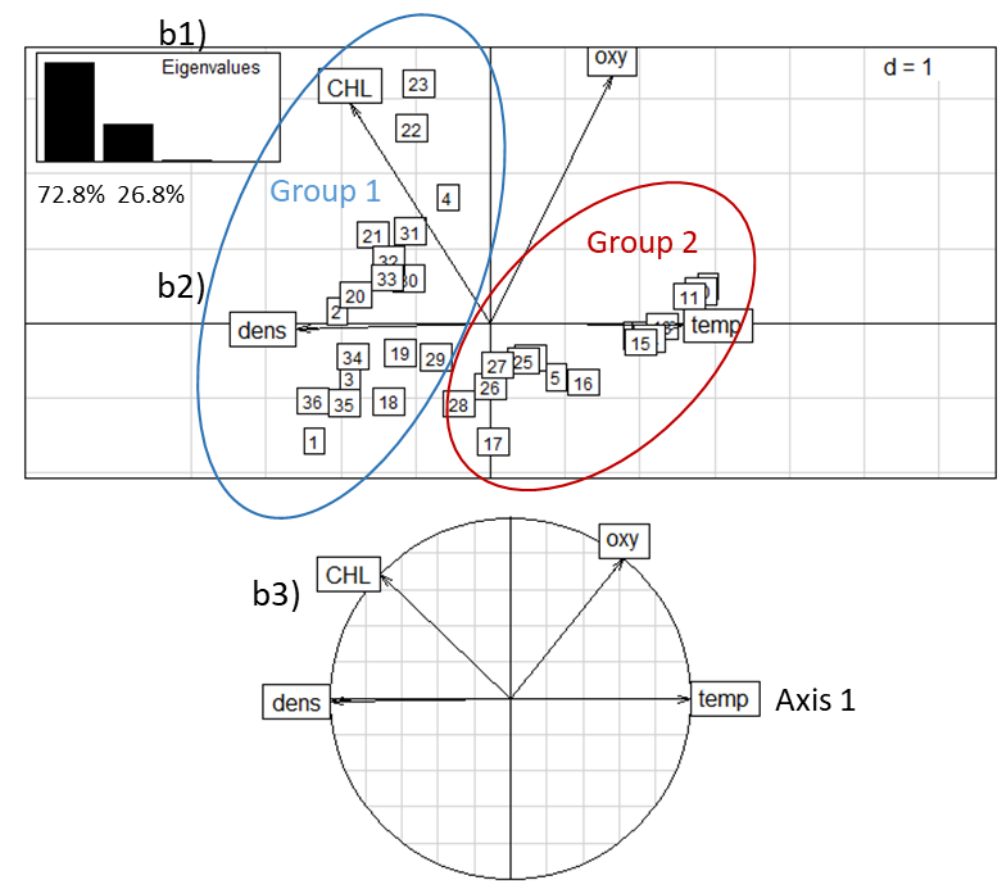

Axis 2

Figure 3. Discrimination of 36 CTD stations off the Senegalese coast: (1) two groups of stations were discriminated based on temperature (temp), chlorophyll $a$ (CHL), dissolved oxygen (oxy), and density (dens). (2) Principal component analysis of environmental parameters for all 36 stations. (a) Eigenvalue diagram; (b) factor plane; (c) correlation circle. Group 1 represents stations located in the inshore area $(n=18)$; Group 2 represents stations located in the offshore area $(n=18)$.

the coast (inshore area, from 13 to $61 \mathrm{~m}$ bottom depth, which encompassed the core of the upwelling (based on data for sea surface temperature) (Fig. 1). Group 2 (G2) stations ( $n=18)$ comprised seven stations along transect R1, six stations along transect R2, and five stations along transect R3. These stations were located furthest from shore (offshore area), from 41 to $205 \mathrm{~m}$ bottom depth, which corresponds to the outer border of the upwelling zone. Considering the bathymetry, we note an overlay of the two areas discriminated between 41 and $61 \mathrm{~m}$.

PCA identified the same two distinct water masses that were clustered in HCA (Fig. 3). Axis 1 of the PCA eigenvalues explained $72.8 \%$ of the inertia, whereas axis 2 explained
$26.8 \%$. On axis 1 of the PCA plot, temperature was highly correlated with density. On axis 2, temperature and DO were opposed to CHL. The distribution of these variables is related to the station groupings: G1 (inshore area) was characterized by a dense and CHL-rich water mass, whereas G2 (offshore area) was characterized by a warm and slightly oxygenated surface water mass.

Satellite measurements of SST distributions of the study area indicated the same split of stations into two groups (Fig. S6). The inshore area was characterized by low SST values $\left(18-19^{\circ} \mathrm{C}\right)$, indicating a recently upwelled water mass, whereas an older water mass with higher SST values $\left(20-21^{\circ} \mathrm{C}\right)$ prevailed offshore. 


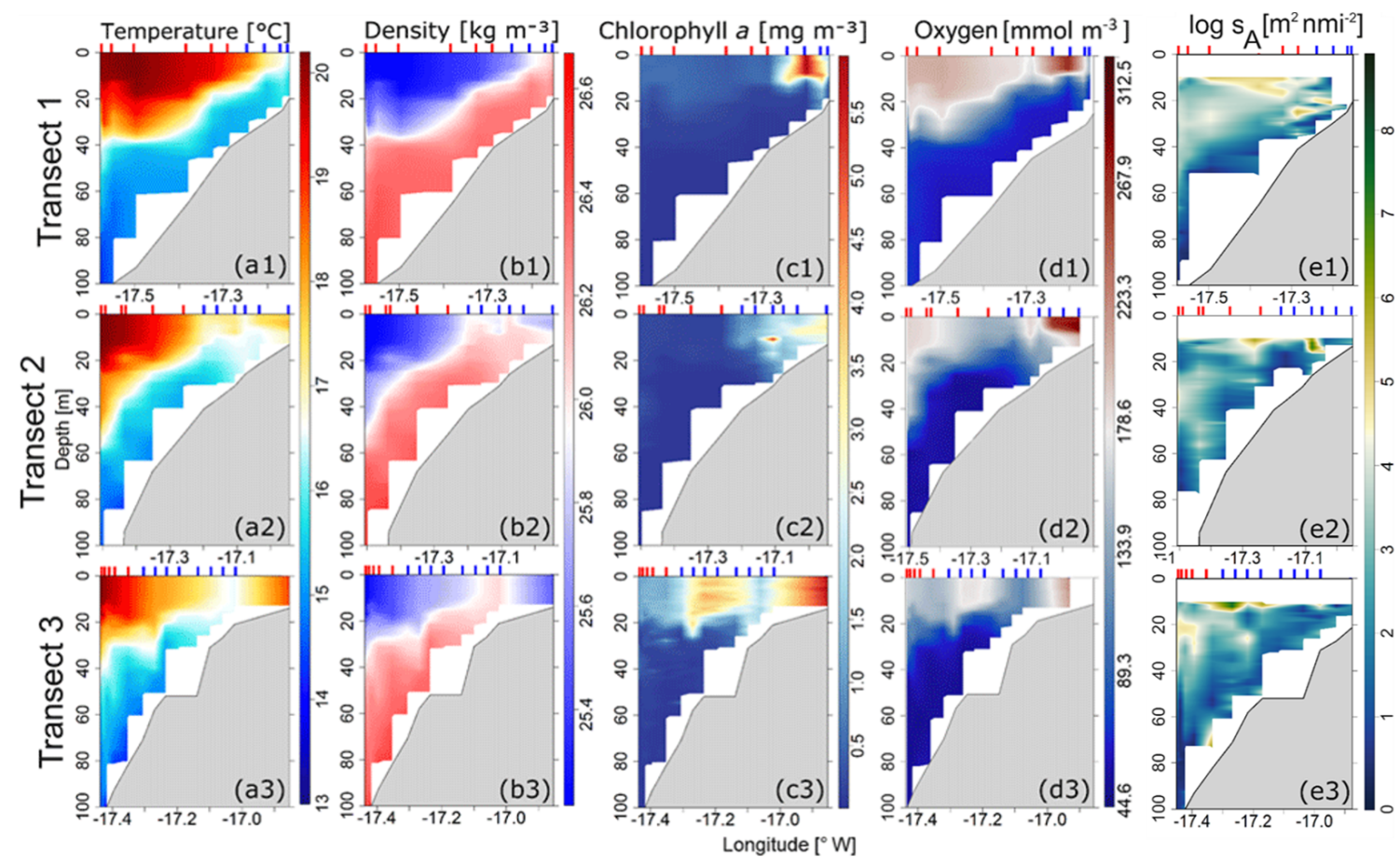

Figure 4. Contour plots of (a) temperature, (b) density, (c) chlorophyll- $a$ concentration, (d) dissolved oxygen, and (e) square rooted nautical area scattering coefficient $\left(s_{\mathrm{A}}\right)$ in the three transects (T1, T2, T3; see Fig. 1) with positions of vertical probe stations CTD in the inshore area (vertical line in blue (G1)) and the offshore area (vertical line in red (G2)).

At transect T1, a marked frontal zone appeared isolating two water masses between the 20 and $40 \mathrm{~m}$ isobaths (Fig. 4a1), which separated warm surface waters from deep, cold, upwelled water masses. At transects T2 and T3, the upwelling appeared as a cold-water tongue isolating a warm water band at the coast (Fig. 4a2, a3). At T3, this cold-water tongue was expanding toward the inshore area as well as to the offshore area (Fig. 4a3). Surface water masses of the inshore area were slightly denser than water masses in the offshore area with approximately 26 and $25 \mathrm{~kg} \mathrm{~m}^{-3}$, respectively. For CHL, elevated concentrations were exclusively observed in the inshore area at transects T1 and T2. CHL was significantly higher in the inshore area than the offshore area with concentrations of $3.0-5.0 \mathrm{mg} \mathrm{m}^{-3}$ in the inshore area to $0.3-2.0 \mathrm{mg} \mathrm{m}^{-3}$ in the offshore area (Fig. 4c). At T3, the elevated CHL concentrations were observed in both inshore and offshore areas close to the upwelling front. CHL was higher in the upper part of the water column $(0-20 \mathrm{~m})$, decreasing with depth in both areas. Higher DO concentrations were observed towards both sides of the upwelling core. At T1, the upwelling front was at the most coastal part, separating the inshore area from the less oxygenated offshore area with DO concentrations of $223-312$ and $178-223 \mathrm{mmol} \mathrm{m}^{-3}$, respectively. At T2 and T3, the core moved towards the offshore, separating the inshore area (DO concentrations of $178-223 \mathrm{mmol} \mathrm{m}^{-3}$ ), slightly more oxygenated than the offshore area (DO concentrations of $89-178 \mathrm{mmol} \mathrm{m}^{-3}$ ). DO concentration decreased from the surface to bottom in both areas.

\subsection{Variability in vertical structure of SSLs}

\subsubsection{Spatial variability according to water mass characteristics}

Thickness and depth of the SSLs varied according to bottom depth in the inshore area and the offshore area. In the inshore area, on the northern transect T1, no SSLs were observed at coastal stations shallower than $29 \mathrm{~m}$ bottom depth (stations 1 and 2) (Fig. 5a). In offshore stations, starting at $41 \mathrm{~m}$ bottom depth, the SSLs were observed in all stations and transects (Fig. 5b), and their thickness and depth increased with bottom depth. SSL thickness and SSL depth differed significantly between the inshore area and the offshore area: the SSLs were thicker and deeper in the offshore area than in the inshore area (Fig. 6) ( $p$ value $=0.001$ for both thickness and depth). An increase of SSL was observed with increasing bottom depths in the inshore area and the offshore area. The $s_{\mathrm{A}}$ comparison between the inshore area and the offshore area (Fig. 6) was not significantly different ( $p$ value $=0.833$ ).

\subsubsection{Diel migration}

The diel period had a significant effect on SSL thickness ( $p$ value $<0.001)$ and SSL depth ( $p$ value $<0.001)$, which 
TRANSECT 1

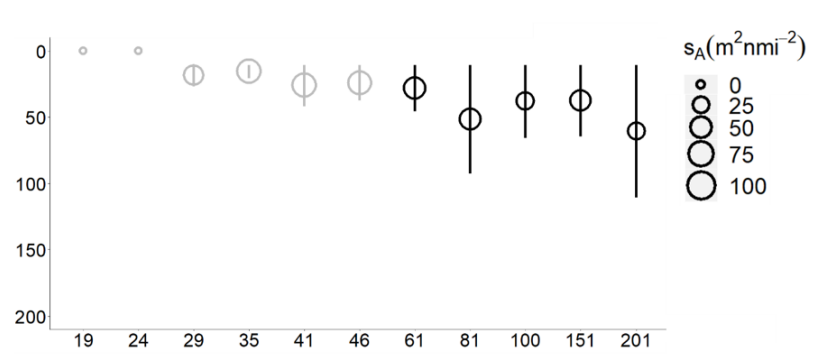

TRANSECT 2

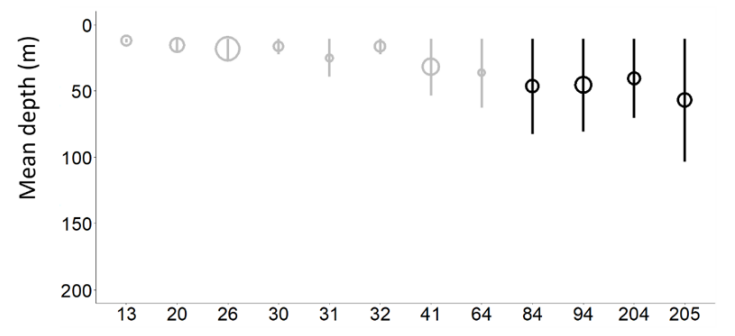

TRANSECT 3

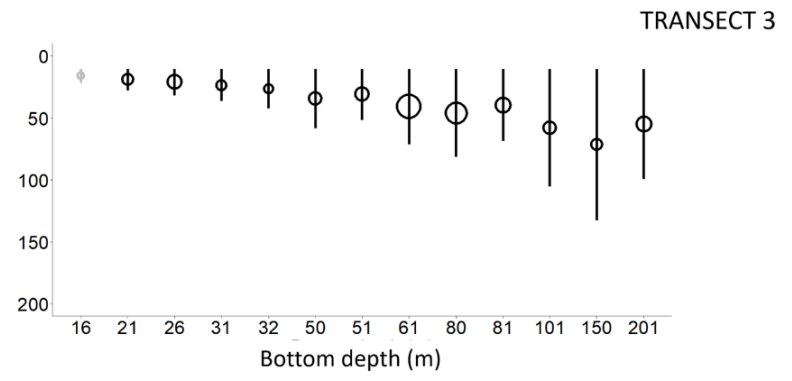

Figure 5. Sound-scattering layer (SSL) mean depths (empty circle) according to their bottom depth, with their associated thickness (line, in meters) and SSL mean nautical area scattering coefficient (NASC or $s_{\mathrm{A}}$ in $\mathrm{m}^{2} \mathrm{nmi}^{-2}$ ), along transect 1 (south), transect 2 (intermediary), and transect 3 (north) during nighttime (black) and daytime (gray) sampling periods.

were found higher during both the night in the inshore area and the offshore area (Fig. 6). In the inshore area, during daytime, the mean depth and thickness of SSL were 19 and $11 \mathrm{~m}$, respectively, while during nighttime the mean depth and thickness were 46 and $35 \mathrm{~m}$, respectively. In the offshore area, SSLs were found at a mean depth and thickness of 49 and $38 \mathrm{~m}$, respectively, during daytime, while during nighttime SSL depth and thickness were 86 and $75 \mathrm{~m}$, respectively. Mean $s_{\mathrm{A}}$ (Fig. 6) of SSLs also varied between day and night but were not significantly different ( $p$ value $=0.890$ ). In the inshore area, the mean $s_{\mathrm{A}}$ was $24 \mathrm{~m}^{2} \mathrm{nmi}^{-2}$ during the day and $44 \mathrm{~m}^{2} \mathrm{nmi}^{-2}$ during the night. In the offshore area, the mean $s_{\mathrm{A}}$ was $46 \mathrm{~m}^{2} \mathrm{nmi}^{-2}$ during daytime and $25 \mathrm{~m}^{2} \mathrm{nmi}^{-2}$ during nighttime. Mean $S_{\mathrm{v}}$ distribution of SSLs (Fig. S7) also showed a diel variation with mean $S_{\mathrm{v}}$ higher at night than during the day.

\subsubsection{Vertical dimension of SSLs related to physicochemical profile}

In both areas, SSLs were partially or completely located in areas of strong vertical gradients of temperature (thermocline), density (pycnocline), and DO (oxycline) (Fig. 2). When a strong temperature gradient was observed, usually also associated with the vertical position of the oxycline and a pycnocline, a peak of CHL was often observed and matched with the volume backscattering strength $\left(S_{\mathrm{v}}\right)$ peak (Fig. 2a). This observation is well illustrated in CTD stations 12, 13, 16, and 25 (Fig. S8). In the inshore area the peak of CHL concentration was always located above the SSLs (Fig. 2a), whereas in the offshore area, the peak of CHL concentration was either above the SSLs or in the middle of the SSLs (Fig. 2b). The thickest SSLs were observed in the offshore area where temperature, density, and oxygen gradients were strong.

\subsubsection{Behavior of the SSLs relative to pelagic habitat characteristics}

\section{In the inshore area (G1)}

In the inshore area (G1), the ANCOVA model indicated a strong effect of bottom depth and diel period on both SSL thickness and depth. For SSL thickness, the model (Tables 1, S1 in the Supplement) explained $87 \%$ of the variance $\left(R^{2}=0.869, p\right.$ value $\left.=0.001\right)$. Bottom depth explained $56 \%$ of SSL thickness, while the diel period effect accounted for $31 \%$. The model of SSL depth (Tables 2, S2) was like those of SSL thickness; i.e., the model included bottom depth and diel period explaining $80 \%$ of the variance $\left(R^{2}=0.805\right.$, $p$ value $=0.001)$. Bottom depth showed the largest effect on SSLs explaining $51 \%$ of SSL depth, while the diel period effect was estimated at $30 \%$. For SSL acoustic density, i.e., $\log \left(s_{\mathrm{A}}\right)$ (Tables $\left.3, \mathrm{~S} 3\right)$, the model explained $40 \%$ of the variance $\left(R^{2}=0.398, p\right.$ value $\left.=0.022\right)$, indicating a single effect of bottom depth on $\log \left(s_{\mathrm{A}}\right)$ ( $p$ value $\left.=0.020\right)$. The bottom depth was the only variable significant in the model and explained $33 \%$ of SSL acoustic density. Temperature was insignificant in the model.

The ANCOVA models to predict SSL thickness and SSL depth can be expressed as

$\mathrm{SSL}_{\text {thickness }}=-11.865+\left(0.916 \times B_{\mathrm{d}}\right)+\left(11.492 \times D_{\mathrm{p}}\right)$, $\mathrm{SSL}_{\text {depth }}=-4.223+\left(0.954 \times B_{\mathrm{d}}\right)+\left(12.864 \times D_{\mathrm{p}}\right)$,

with $B_{\mathrm{d}}$ being bottom depth in meters and $D_{\mathrm{p}}$ being diel period at night.

\section{In the offshore area (G2)}

For offshore stations, the model showed a significant effect of diel period, temperature, water density, and DO on both thickness and depth of SSLs with similar results. Both models, SSL thickness (Tables 1, S1), and SSL depth (Tables 2, 
(a)
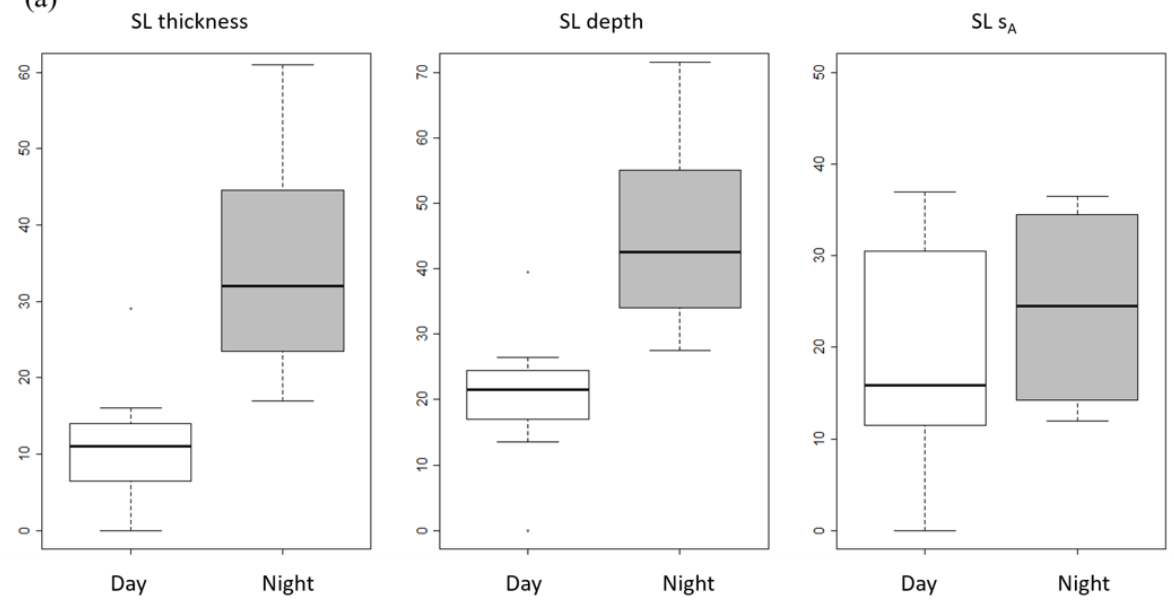

(b)
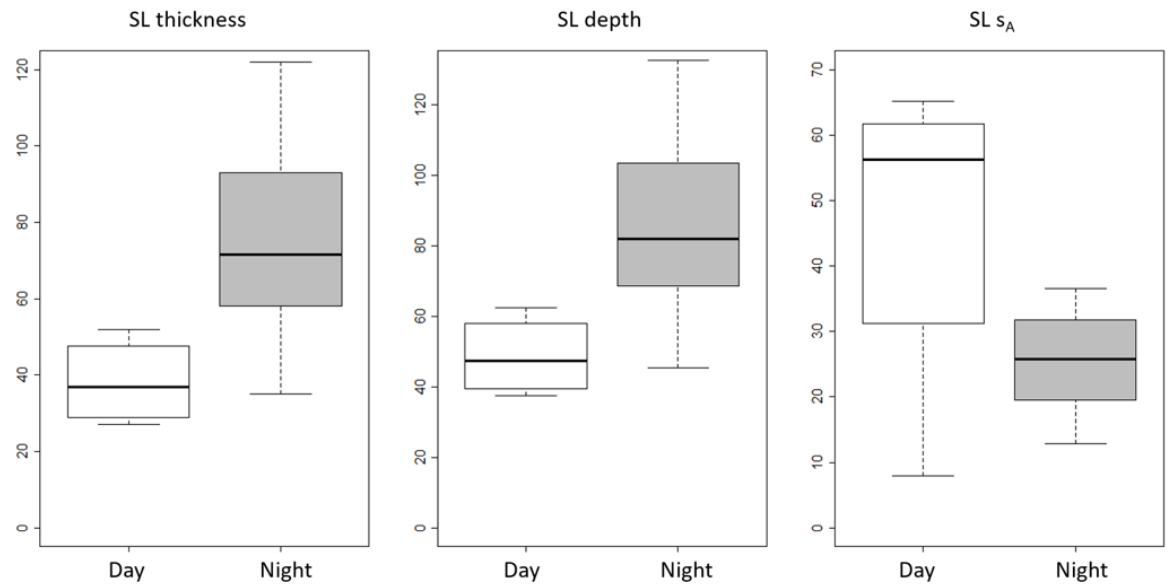

Figure 6. Box plot (minimum, maximum, and median) of sound-scattering layers (SSLs) mean depth (m), thickness (m), and relative biomass $\left(s_{\mathrm{A}}\right.$ in $\mathrm{m}^{2} \mathrm{nmi}^{-2}$ ) grouped by diel period (day and night) for (a) inshore area and (b) offshore area over the Senegalese continental shelf.

S2) included bottom depth, diel period, temperature, density, and DO explaining $85 \%$ of variance $\left(R^{2}=0.855, p\right.$ value $=0.001)$. Bottom depth and diel period accounted for $28 \%$ and $28 \%$, respectively. Other significant variables were water temperature, density, and DO, which support $11 \%, 10 \%$, and $7 \%$, respectively. For SSL density or $\log \left(s_{\mathrm{A}}\right)$ (Tables 3, S3), none of the predictor variables had a significant effect.

The ANCOVA models to predict SSL thickness and SSL depth can be expressed as

$$
\begin{aligned}
\mathrm{SSL}_{\text {thickness }} & =56030+\left(0.21 \times B_{\mathrm{d}}\right)+\left(27.35 \times D_{\mathrm{p}}\right) \\
& +(-383.80 \times T)-(1898 \times D)-\left(1.76 \times \mathrm{O}_{2}\right), \\
\mathrm{SSL}_{\text {depth }}= & 56040+\left(0.21 \times B_{\mathrm{d}}\right)+\left(27.35 \times D_{\mathrm{p}}\right) \\
+ & (-383.80 \times T)-(1898 \times D)-\left(1.76 \times \mathrm{O}_{2}\right),
\end{aligned}
$$

with $B_{\mathrm{d}}$ being bottom depth in meters, $D_{\mathrm{p}}$ being diel period at night, $T$ being water temperature in degrees Celcius $\left({ }^{\circ} \mathrm{C}\right), D$ being water density $\left(\mathrm{kg} \mathrm{m}^{-3}\right)$, and $\mathrm{O}_{2}$ being oxygen $\left(\mathrm{mmol} \mathrm{m}^{-3}\right)$.

\section{Discussion}

\subsection{Characterization of water masses along the Petite Côte}

Upwelling is a key process for the functioning of the coastal ecosystem of Senegal and Mauritania (Capet et al., 2016; Estrade et al., 2008; Rebert, 1983). By characterizing the physicochemical parameters of the Petite Côte, we were able to discriminate two water masses: an inshore area and the offshore area, both of which could also be distinguished with SST satellite data.

Analyzing the spatial structure of SST helped to understand the upwelling dynamics along the Petite Côte. The SST pattern, measured at the time of our survey, was in line with prior studies. During the upwelling season (in winter and late spring), a tongue of cold water over the shelf isolates a coastal band of warm water from the offshore area, and there is a surface separation associated with the upwelling source over the shelf and convergence nearshore. The spa- 
Table 1. Result of ANCOVA models between thickness of sound-scattering layers (SSLs) and environmental parameters (temperature, density, dissolved oxygen, chlorophyll $a$, diel period, and bottom depth) in the inshore area (G1) and the offshore area (G2). G1: multiple $R^{2}$ is 0.869 , adjusted $R^{2}$ is 0.8515 , and $p$ value $<0.001$; G2: multiple $R^{2}$ is 0.8557 , adjusted $R^{2}$ is 0.7956 , and $p$ value $<0.001$; significant $p$ values in bold.

\begin{tabular}{lrr|rr|rr}
\hline Variable & \multicolumn{2}{c|}{ Significance } & \multicolumn{2}{|c|}{ Explained deviance (\%) } & \multicolumn{2}{|c}{$\begin{array}{c}\text { Total explained } \\
\text { variance (\%) }\end{array}$} \\
\cline { 2 - 7 } & \begin{tabular}{rr|rrr} 
Inshore \\
$(\mathrm{G} 1)$
\end{tabular} & $\begin{array}{r}\text { Offshore } \\
(\mathrm{G} 2)\end{array}$ & $\begin{array}{r}\text { Inshore } \\
(\mathrm{G} 1)\end{array}$ & $\begin{array}{r}\text { Offshore } \\
(\mathrm{G} 2)\end{array}$ & $\begin{array}{r}\text { Inshore } \\
(\mathrm{G} 1)\end{array}$ & $\begin{array}{r}\text { Offshore } \\
(\mathrm{G} 2)\end{array}$ \\
\hline Bottom depth & $\mathbf{0 . 0 0 1}$ & $\mathbf{0 . 0 0 5}$ & 55.86 & 28.05 & & \\
Diel period (night) & $\mathbf{0 . 0 0 7}$ & $\mathbf{0 . 0 0 8}$ & 31.02 & 28.33 & & \\
Temperature & & $\mathbf{0 . 0 0 7}$ & & 11.29 & 86.9 & 85.57 \\
Density & & $\mathbf{0 . 0 0 8}$ & & 10.35 & & \\
Oxygen & & $\mathbf{0 . 0 0 7}$ & & 7.53 & & \\
\hline
\end{tabular}

Table 2. Result of ANCOVA models between depth of sound-scattering layers (SSLs) and environmental parameters (temperature, density, dissolved oxygen, chlorophyll $a$, diel period, and bottom depth) in the inshore area (G1) and the offshore area (G2). G1: multiple $R^{2}$ is 0.8056 , adjusted $R^{2}$ is 0.7797 , and $p$ value is 0.001 ; G2: multiple $R^{2}$ is 0.8557 , adjusted $R^{2}$ is 0.7956 , and $p$ value is 0.000 ; significant $p$ values in bold.

\begin{tabular}{lrr|rr|rr}
\hline Variable & \multicolumn{2}{c|}{ Significance } & Explained deviance (\%) & \multicolumn{2}{|c}{$\begin{array}{c}\text { Total explained } \\
\text { variance (\%) }\end{array}$} \\
\cline { 2 - 7 } & \begin{tabular}{rr|rrr} 
Inshore \\
$(\mathrm{G} 1)$
\end{tabular} & $\begin{array}{r}\text { Offshore } \\
(\mathrm{G} 2)\end{array}$ & $\begin{array}{r}\text { Inshore } \\
(\mathrm{G} 1)\end{array}$ & $\begin{array}{r}\text { Offshore } \\
(\mathrm{G} 2)\end{array}$ & $\begin{array}{r}\text { Inshore } \\
(\mathrm{G} 1)\end{array}$ & $\begin{array}{r}\text { Offshore } \\
(\mathrm{G} 2)\end{array}$ \\
\hline Bottom depth & $\mathbf{0 . 0 0 1}$ & $\mathbf{0 . 0 0 5}$ & 55.86 & 28.05 & & \\
Diel period (night) & $\mathbf{0 . 0 2 1}$ & $\mathbf{0 . 0 0 8}$ & 31.02 & 28.33 & & \\
Temperature & & $\mathbf{0 . 0 0 7}$ & & 11.29 & 80.56 & 85.57 \\
Density & & $\mathbf{0 . 0 0 8}$ & & 10.35 & & \\
Oxygen & & $\mathbf{0 . 0 0 7}$ & & 7.53 & & \\
\hline
\end{tabular}

tial difference of CHL concentration between the inshore area and the offshore area is the result of upwelled water carrying nutrients to the coast, which is separated by water mass fronts. Nutrient-rich water, supplied to the sunlit surface layer by wind-driven upwelling, stimulates the growth of phytoplankton that ultimately fuel diverse and productive marine ecosystems (Jacox et al., 2018). There is a link between the accumulation of biological material and the location of the coastal band of warm water. This coastal band between coast and the upwelling core has been regarded to function as a retention area in which nutrient particles are trapped (Demarcq and Faure, 2000; Roy, 1998). The nutrient utilization is optimized by retentive physical mechanisms in the coastal area, which enhances microbial remineralization of particulate organic matter and zooplankton excretion and then regenerates production through ammonium consumption (Auger et al., 2016). This causes an increase in primary production and results in a surplus of phytoplankton biomass in inshore areas. Low DO concentrations observed in the upwelling core separating more oxygenated water masses have been reported in previous studies (Capet et al., 2016; Teisson, 1983) over the Petite Côte. Once a water mass becomes isolated from the atmosphere, its oxygen content starts to de- crease due to biological remineralization of dissolved organic matter (Emerson et al., 2008; Machu et al., 2019). These low-oxygen bottom waters are transported to the inner shelf during upwelling-favorable wind events. Moreover, temporal stability of the upwelling core is also noticeable over periods of several days to weeks, and export from the shelf to the open ocean is retarded (Capet et al., 2016). Thus, in such favorable conditions of continuous food supply, photosynthesis may foster an enrichment of DO in the inshore. This is in line with high CHL levels observed towards both sides of the upwelling core, particularly in the inshore area.

\subsection{Spatial variation of the SSLs off the Petite Côte of Senegal}

We measured a longitudinal gradient of the thickness of the SSLs over the continental shelf. The SSLs were concentrated in a narrow band in the inshore area, whereas the SSLs were wider in the offshore zone. The absence or weakness of SSLs in the inshore area (in contrast to the more stratified water column in the offshore area) may have been due to turbulence in the water column (Sengupta et al., 2017), coupled with a well-mixed surface layer. In the inshore area, it is 
likely that turbulence and the probable low residence time of marine pelagic organisms advected from outside this area and both inhibited SSL formation. Indeed, in such upwelling systems, in addition to the retention mechanism that has been recognized by several authors (Arístegui et al., 2009; Capet et al., 2016; Mbaye et al., 2015; Roy, 1998), there is also an offshore Ekman transport mechanism (Arístegui et al., 2009; Estrade et al., 2008) that contributes to crossshore exchanges. Otherwise, different animals can respond very differently to different physical forcing. Many authors have stressed that SSLs need stable hydrological conditions to form (Aoki and Inagaki, 1992; Baussant et al., 1992; Marchal et al., 1993). As an example, in Monterey Bay (California), Urmy and Horne (2016) observed a decline in acoustic backscatter intensity in the upper part of the water column immediately following an upwelling event. In a more recent study, Benoit-Bird et al. (2019) found that when upwelling was strong both krill and anchovies were found in small, discrete aggregations, while during upwelling relaxation and reversals forage biomass was more diffusely distributed. Therefore, we assume that the increase of SSL thickness with depth from inshore to offshore off Senegal is caused by upwelled waters that disrupt the vertical stability of the water column. Therefore, although the SSLs are first constrained by the bottom depth (i.e., room available), we assume that the increase of SSL thickness with depth from inshore to offshore off Senegal is caused by upwelled waters that disrupt the vertical stability of the water column.

\subsection{Diel temporal variation of SSLs}

In our study area, the diel period consistently exhibited pronounced effects on SSL thickness and depth. Deeper nighttime SSLs have a greater thickness than daytime SSLs. The diel difference in thickness and depth is due to the wellknown DVM patterns performed by many marine species. DVM is a behavioral mechanism usually characterized by an ascent during nighttime for feeding and a descent to avoid predation by visual predators during daytime known as type I (Bianchi et al., 2013; Haney, 1988; Lehodey et al., 2015). Some planktonic and micronektonic organisms have been reported to exhibit reverse DVM (type II), i.e., ascending in the morning and descending in the evening or early night, which is the opposite pattern generally observed with vertically migrating animals (Cushing, 1951; Ohman et al., 1983). The main SSL scatters much more strongly at $38 \mathrm{kHz}$ than at 70 or $120 \mathrm{kHz}$ (Fig. 2); the backscattering response is probably dominated by animals with swim bladders such as fish larvae and small fish (Simmonds and MacLennan, 2005a). Indeed, the Petite Côte is a nursery area for fish and is the main area in which juveniles of numerous species concentrate (Diankha et al., 2018; Thiaw et al., 2017). Moreover, Tiedemann and Brehmer (2017) have reported fish larvae (Sardinella aurita, Engraulis encrasicolus, Trachurus trachurus, Trachurus trecae, Microchirus ocellatus, and Hygophum macrochi) all along our study area. Previous studies reported that DVM of plankton may increase coastal retention in the inshore area (Brochier et al., 2018; Mbaye et al., 2015; Rojas and Landaeta, 2014). Diel variation was also observed for SSL acoustic density, which showed opposite patterns in the two areas, i.e., higher up in the water column during night than day in the inshore area and higher up during days than at night in the offshore area. Tiedemann and Brehmer (2017) observed that all fish larvae in the offshore area, except Trachurus trachurus, exhibited a DVM type II, and their observations are in accordance with the DVM pattern of SSL acoustic density reported in our study. Another possible explanation of this observed diel variation is the horizontal migration. DHMs are known as nocturnal horizontal migration of both plankton and consumers into shallow and inshore waters (Benoit-Bird et al., 2001; Benoit-Bird and Au, 2006). DHMs have been observed in marine copepods (Suh and Yu, 1996) which represent the main zooplankton group in the study area (Ndour et al., 2018; Rodrigues et al., 2017). It is hypothesized that these inshore-offshore migrations are a strategy for avoiding visual predators (White, 1998), and they result in increased access to food resources relative to simple vertical migration (Benoit-Bird et al., 2008). Otherwise, DVM of marine pelagic organisms may not be the only factor causing diel backscatter variations.

i. The acoustic target strength can be strongly dependent on the aspect at which a target is insonified. Target strengths of zooplankton and micronekton can vary by several orders of magnitude between extreme tilt angles, i.e., horizontal vs. head up or head down (Benoit-Bird and $\mathrm{Au}, 2004$; Yasuma et al., 2003). Target strength is not independent of depth, as migrations through the hydrostatic depth gradient can alter, e.g., swim bladder volume (Fässler et al., 2009). This can bias target strengths, in particular near the resonance frequency, leading to artificial increases of backscatter at a particular depth (Davison et al., 2015; Godø et al., 2009; Kloser et al., 2002).

ii. In the inshore area the CTD sampling was mainly achieved during the daytime, which may have biased the observed DVM type I.

iii. Otherwise, plankton such as fish larvae are able to perform a DVM type II by ascending in the upper $10 \mathrm{~m}$ of the water column at night, i.e., in the echo sounder offset.

\subsection{Effect of environmental parameters on SSLs}

\subsubsection{SSLs related to physicochemical parameters in the vertical dimension}

Previous studies have shown that hydrographic structures of the water column influence SSL vertical structure (Balino 
Table 3. Result of ANCOVA models between sound-scattering-layer (SSL) density $\left(\log \left(s_{\mathrm{A}}\right)\right)$ and environmental parameters (temperature, density, dissolved oxygen, chlorophyll $a$, diel period, and bottom depth) in the inshore area (G1) and the offshore area (G2). G1: multiple $R^{2}$ is 0.398 , adjusted $R^{2}$ is 0.3178 , and $p$ value is 0.022 ; G2: multiple $R^{2}$ is 0.3448 , adjusted $R^{2}$ is -0.01258 , and $p$ value is 0.490 ; significant $p$ values in bold.

\begin{tabular}{lrr|rr|rr}
\hline Variable & \multicolumn{2}{c|}{ Significance } & \multicolumn{2}{|c|}{ Explained deviance (\%) } & \multicolumn{2}{|c}{$\begin{array}{c}\text { Total explained } \\
\text { variance (\%) }\end{array}$} \\
\cline { 2 - 7 } & \begin{tabular}{rr|rrr} 
Inshore \\
$(\mathrm{G} 1)$
\end{tabular} & $\begin{array}{r}\text { Offshore } \\
(\mathrm{G} 2)\end{array}$ & $\begin{array}{r}\text { Inshore } \\
(\mathrm{G} 1)\end{array}$ & $\begin{array}{r}\text { Offshore } \\
(\mathrm{G} 2)\end{array}$ & $\begin{array}{r}\text { Inshore } \\
(\mathrm{G} 1)\end{array}$ & $\begin{array}{r}\text { Offshore } \\
(\mathrm{G} 2)\end{array}$ \\
\hline Bottom depth & $\mathbf{0 . 0 0 8}$ & 0.357 & 33.06 & 7.56 & & \\
Temperature & 0.119 & 0.273 & 6.73 & 5.17 & & \\
Diel period (night) & & 0.007 & 0.546 & 7.22 & 39.8 & 34.48 \\
Density & & 0.008 & 0.250 & 5.56 & & \\
Oxygen & & 0.007 & 0.166 & 5.19 & & \\
\hline
\end{tabular}

and Aksnes, 1993; Berge et al., 2014; Gausset and Turrel, 2001). In our case study the results show that vertical distribution of SSLs was linked to strong vertical gradients of temperature, DO, and water density (Fig. 2). The peak of $S_{\mathrm{v}}$ was sometimes very close to the strong gradient of water temperature, density, CHL, and DO (Fig. S8). The depth of SSLs has been reported to be related to the thermocline (Marchal et al., 1993; Yoon et al., 2007). In more stratified areas, SSL vertical distribution was limited by a strong thermocline and when thermocline was not well marked (low gradient) SSLs occupied the entire water column (Lee et al., 2013). Olla and Davis (1990) and Rojas and Landaeta (2014) suggested that the thermocline is a physical barrier that acts above or below in the vertical distribution of some fish larvae, while other studies (Gray and Kingsford, 2003; Tiedemann and Brehmer, 2017) showed no effect of a thermocline on vertical larval fish distributions. In this study, the SSL was correlated to temperature in the offshore stratified area, but it did not act as a physical barrier limiting vertical distribution. Previous studies (Bertrand et al., 2010; Bianchi et al., 2013; Netburn and Koslow, 2015) have suggested that vertical distributions of SSL organisms are limited by mid-water DO concentrations which constrain SSL depth. These authors found a relationship between SSL depths and hypoxia. However, in our study, we found correlations between SSLs (depth, thickness) and DO as expected, but the vertical distribution of SSLs was not constrained by DO. SSLs were also observed in some hypoxic stations ( $\mathrm{DO}<1.42 \mathrm{~mL} \mathrm{~L}^{-1}$, i.e., $63.42 \mathrm{mmol} \mathrm{m}^{-3}$ ); consequently, DO was not a limiting factor for SSLs organisms. Fish larvae respond to oxygen gradients by moving upwards or laterally (Breitburg, 2002, 1994). Vertical movement of fish larvae may also be related to the avoidance of predators, which are limited to well-oxygenated layers. The high phytoplankton concentration found in this study, particularly in the inshore area, may be interpreted as a potential food source for fish larvae, which are able to perform DVM towards the surface. The vertical position of SSLs compared to the CHL concentration peak can be explained by trophic relationships between phytoplankton, zooplankton, and micronekton. It is understood that zooplanktivorous micronekton migrates upward in the water column to forage on mesozooplankton while the mesozooplankton is migrating toward the surface to graze upon the phytoplankton. This trophic relationship may explain the link in vertical position of the SSLs with the phytoplankton peak reported in this study.

\subsubsection{Behavior of SSLs relative to pelagic habitat characteristics}

In the inshore area, where SSLs were sparsely present (or sometimes non-existent) bottom depth and diel period were the main environmental parameters influencing the vertical distribution (thickness and depth) of the SSLs. Bottom depth has been shown to regulate the vertical distribution of SSLs in the water column (Donaldson, 1967; Gausset and Turrel, 2001; Torgersen et al., 1997). In our study, all stations indicated a single SSL, while in deep water more thick and deep SSLs are often partitioned into multiple layers (Ariza et al., 2016; Balino and Aksnes, 1993; Cascão et al., 2017; Gausset and Turrel, 2001). Diel period is the second most important parameter acting on SSL thickness and depth through the DVM phenomenon. In well-mixed water masses, temperature, density, and oxygen had no effect on the SSLs. The insignificant effect of temperature, oxygen, and water density on the SSLs in the inshore area is explained by the presence of less marked and superficial clines because of the newly upwelled water. As stated above, SSLs probably need stable conditions to occur.

In the offshore area, where vertical gradients were marked, the main parameters structuring SSL thickness and depth were bottom depth and diel period but also water temperature, density, and DO. DVM behaviors are influenced by environmental cues (e.g., light, nutrients, and temperature) and predator-prey interactions (Clark and Levy, 1988; Lampert, 1989). Relative changes in light intensity are identified as the most important proximate stimuli driving DVM, in- 
cluding the amplitude of the migration as well as the timing of the up- and downward movement (Meester, 2009). SSL vertical distribution is also known to be a function of temperature (Bertrand et al., 2010; Hazen and Johnston, 2010; Netburn and Koslow, 2015). Overnight, depths of the SSLs are strongly correlated to the depth of thermal and density gradients (Boersch-Supan et al., 2017; Cascão et al., 2017; Marchal et al., 1993). In the offshore area, the results suggest that DO also influences SSL depth and SSL thickness. In welloxygenated continental shelf waters, DO influences SSLs but does not limit their vertical distribution. Some previous work in French Polynesia (Bertrand et al., 2000), and in the southern California current ecosystem (Netburn and Koslow, 2015), showed that the oxygen minimum zone (OMZ) acts like a barrier to SSLs in their vertical distribution. Bianchi et al. (2013) suggest that distribution of the open-ocean OMZ may modulate the depth of migration at the large scale so that organisms within SSLs migrate to shallower waters in lowoxygen regions and to deeper waters in well-oxygenated waters. For both areas, CHL concentration was the only predictor that was not included in any of the final models. However, by coupling echogram and profile data (Fig. 2), we can argue that a relation between CHL and SSLs exists even if it was not significant in the models, because CHL and SSL biomass peaks matched, i.e., always located above or in the middle of the SSLs. Moreover, a simple linear model between CHL and SSL structure (depth and thickness) was significant in the inshore area, suggesting that the effect of CHL on full models was masked by autocorrelation between predictive variables.

Fish larvae vertical distributions have been related to the distribution of their prey and predator, and it has been argued that the presence and position of the thermocline is an important feature in their vertical distribution (Haney, 1988; Röpke, 1993). Other studies have shown that the thermocline has only a limited role in the vertical distribution patterns of fish larvae (Gray, 1996; Gray and Kingsford, 2003). Indeed, in coastal areas, where the structure of the water column is less regular than in the open sea, the vertical distribution of fish larvae depends on the physics of the water column (Sánchez-Velasco et al., 2007) but also on the behavior of each species (Fortier and Harris, 1989). According to Sánchez-Velasco et al. (2007), the vertical distribution of fish larvae is closely related to the changes in the water column structure, with most fish larvae concentrated in the stratum of maximum stability. Therefore, the vertical stratification level in water column is strongly related to vertical distribution of these organisms.

Furthermore, the vertical distribution of SSLs can be influenced by mixed layer depth (MLD). The MLD is one of the primary factors affecting the vertical distribution of zooplankton. Lee et al. (2018) have shown that the weighted mean depths of SSLs exhibit a strong linear relationship with the MLD, meaning that the MLD could be a significant environmental factor controlling the habitat depth of marine pelagic organisms. A recent study (Stranne et al., 2018) has shown that the MLD can be tracked acoustically at high horizontal and vertical resolutions. The method was shown to be highly accurate when the MLD is well defined and biological scattering does not dominate the acoustic returns. However, in our study area, biological scattering dominated the acoustic records and due to the upwelling acoustic methods were not appropriate to determine MLD.

\section{Conclusions}

Using our echogram vs. profile coupling approach, we were able to examine fine-scale processes affecting SSL distributions. SSLs were influenced by turbulence level in the upwelling, which led to an offshore advection of SSL organisms. SSL distributions were mainly structured by bottom depth, diel period, and the level of vertical stratification in water column. SSL acoustic density variation suggested different diel migrations: a normal and reverse DVM, and/or a DHM. Such an observation should be considered in modeling exercises to better understand DVM implications in ecosystem functioning. Further investigations should integrate small-scale turbulence measurements to better describe the fine-scale spatiotemporal variability of SSLs and their relationship to the pelagic environment. Information on SSL species composition and morphological characteristics will provide an accurate description of their fine-scale relationships in the pelagic habitat.

Code availability. "Matecho" is an open-source tool available at https://svn.mpl.ird.fr/echopen/MATECHO/ (last access: 15 February 2019) (login: userecho, password: echopen). Other MATLAB codes used in this work are "Layer" and "ComparEchoProfil" and are shared in the Supplement sections S1 and S2 of this paper. "Matecho" (Perrot et al., 2018) is an Open-Source Tool available at: https://svn.mpl.ird.fr/echopen/MATECHO/ (login: userecho, password: echopen).

Sample availability. The public cannot access our data because they belong to the partners who funded the oceanographic cruise.

Supplement. The supplement related to this article is available online at: https://doi.org/10.5194/os-16-65-2020-supplement.

Author contributions. ND set the methodology, analyzed data, and redacted the paper and the review. PB was cruise leader on the ECOAO sea survey, defined the sampling design, collected the data, defined the methodology, supervised the work and the review, and took charge of the acquisition of the financial support for the project leading to this publication. MT helped with data processing and analyses, paper redaction, and the review. YP developed the "Matecho" software tool and MATLAB code and contributed to the redaction and data collection. AS, AT, and SEA contributed to the $\mathrm{PhD}$ 
supervision of ND. AM and CM helped with statistical analyses and OS performed the early PCA on CTD data.

Competing interests. The authors declare that they have no conflict of interest.

Acknowledgements. Results of this paper were discussed during international conferences (ICAWA) in Dakar (2016) and in Mindelo (2017). We thank the participants for helpful comments made during these conferences. We are thankful to the AWA project (Ecosystem Approach to Management of Fisheries and Marine Environment in West African Waters), funded by IRD and the BMBF (grant 01DG12073E), and the PREFACE project (Enhancing Prediction of Tropical Atlantic Climate and its Impacts), and the TriAtlas project, as well as all IRD - ISRA/CRODT - Genavir staff for helping us at sea during the survey (https://doi.org/10.17600/13110030, Brehmer, 2017). We thank Gildas Roudaut, Fabrice Roubaud, François Baurand, and the US Imago (IRD) for data collection aboard FRV Antea (IRD), the Gnavir crew of Antea, Dominique Dagorne (IRD) curating satellite products, as well as the personal of ISRA/CRODT (Senegal), IRD DR-Ouest (France) and INRH (Morocco) for their administrative help during Ndague Diogoul $\mathrm{PhD}$ stays in Morocco financed by OWSD (Organization for Women in Sciences for the Developing World). We thank Heino Fock (TI, Germany), as well as the anonymous referee, for their helpful comments on this paper, which significantly improved the paper quality.

Financial support. This research has been supported by the IRDBMBF (grant no. 01DG12073E).

Review statement. This paper was edited by Mario Hoppema and reviewed by Heino Fock and one anonymous referee.

\section{References}

Akaike, H.: A new look at the statistical model identification, IEEE T. Autom. Contr., 19, 716-723, https://doi.org/10.1109/TAC.1974.1100705, 1974.

Akima, H., Gebhardt, A., Petzold, T., and Maechler, M.: akima: Interpolation of Irregularly and Regularly Spaced Data, available at: https://CRAN.R-project.org/package=akima (last access: 8 July 2018), 2016.

Anonymous: Rapport des travaux de recherches scientifiques à bord du navire "ATLANTIDA" réalisés dans la Zone Economique Exclusive (ZEE) du Sénégal (Décembre 2012), Rap. Scient., AtlantNiro, Russie, 2013.

Aoki, I. and Inagaki, T.: Acoustic observations of fish schools and scattering layers in a Kuroshio warm-core ring and its environs, Fish. Oceanogr., 1, 137-142, 1992.

Arístegui, J., Barton, E. D., Álvarez-Salgado, X. A., Santos, A. M. P., Figueiras, F. G., Kifani, S., Hernández-León, S., Mason, E., Machú, E., and Demarcq, H.: Sub-regional ecosystem variability in the Canary Current upwelling, Prog. Oceanogr., 83, 33-48, https://doi.org/10.1016/j.pocean.2009.07.031, 2009.

Ariza, A., Landeira, J. M., Escánez, A., Wienerroither, R., Aguilar de Soto, N., Røstad, A., Kaartvedt, S., and Hernández-León, S.: Vertical distribution, composition and migratory patterns of acoustic scattering layers in the Canary Islands, J. Mar. Syst., 157, 82-91, https://doi.org/10.1016/j.jmarsys.2016.01.004, 2016.

Auger, P.-A., Gorgues, T., Machu, E., Aumont, O., and Brehmer, P.: What drives the spatial variability of primary productivity and matter fluxes in the north-west African upwelling system? A modelling approach, Biogeosciences, 13, 6419-6440, https://doi.org/10.5194/bg-13-6419-2016, 2016.

Balino, B. and Aksnes, D.: Winter distribution and migration of the sound scattering layers, zooplankton and micronekton in Masfjorden, western Norway, Mar. Ecol. Prog. Ser., 102, 35-50, https://doi.org/10.3354/meps102035, 1993.

Baussant, T., Ibanez, F., Dallot, S. and Etienne, M.: Diurnal mesoscale patterns of 50-khz scattering layers across the ligurian sea front (NW mediterranean-sea), Oceanol. Acta, 15, 3$12,1992$.

Belkin, I. M., Cornillon, P. C., and Sherman, K.: Fronts in Large Marine Ecosystems, Prog. Oceanogr., 81, 223-236, https://doi.org/10.1016/j.pocean.2009.04.015, 2009.

Benoit-Bird, K., Au, W., E. Brainard, R., and Lammers, M.: Diel horizontal migration of the Hawaiian mesopelagic boundary community observed acoustically, Mar. Ecol. Prog. Ser., 217, 114, https://doi.org/10.3354/meps217001, 2001.

Benoit-Bird, K. J. and Au, W. W. L.: Diel migration dynamics of an island-associated sound-scattering layer, Deep-Sea Res. Pt. I, 51, 707-719, https://doi.org/10.1016/j.dsr.2004.01.004, 2004.

Benoit-Bird, K. J. and Au, W. W. L.: Extreme diel horizontal migrations by a tropical nearshore resident micronekton community, Mar. Ecol. Prog. Ser., 319, 1-14, https://doi.org/10.3354/meps319001, 2006.

Benoit-Bird, K. J., Zirbel, M. J., and McManus, M. A.: Diel variation of zooplankton distributions in Hawaiian waters favors horizontal diel migration by midwater micronekton, Mar. Ecol. Prog. Ser., 367, 109-123, https://doi.org/10.3354/meps07571, 2008.

Benoit-Bird, K. J., Waluk, C. M., and Ryan, J. P.: Forage Species Swarm in Response to Coastal Upwelling, Geophys. Res. Lett., 46, 1537-1546, https://doi.org/10.1029/2018GL081603, 2019.

Berge, J., Cottier, F., Varpe, O., Renaud, P. E., Falk-Petersen, S., Kwasniewski, S., Griffiths, C., Soreide, J. E., Johnsen, G., Aubert, A., Bjaerke, O., Hovinen, J., Jung-Madsen, S., Tveit, M., and Majaneva, S.: Arctic complexity: a case study on diel vertical migration of zooplankton, J. Plankton Res., 36, 1279-1297, https://doi.org/10.1093/plankt/fbu059, 2014.

Bertrand, A., Misselis, C., Josse, E., and Bach, P.: Caractérisation hydrologique et acoustique de l'habitat pélagique en Polynésie française?: conséquences sur les distributions horizontale et verticale des thonidés, in: Les espaces de l'Halieutique, Actes du quatrième Forum Halieumétrique, edited by: Gascuel, D., Biseau, A., Bez, N., and Chavance, P., 55-74, Paris, available at: http://horizon.documentation.ird.fr/exl-doc/pleins_ textes/divers09-03/010024490.pdf, (last access: 20 November 2019), 2000.

Bertrand, A., Ballón, M., and Chaigneau, A.: Acoustic Observation of Living Organisms Reveals the Upper Limit 
of the Oxygen Minimum Zone, PLOS ONE, 5, e10330, https://doi.org/10.1371/journal.pone.0010330, 2010.

Bertrand, A., Grados, D., Habasque, J., Fablet, R., Ballon, M., Castillo, R., Gutierrez, M., Chaigneau, A., Josse, E., Roudaut, G., Lebourges-Dhaussy, A., and Brehmer, P.: Routine acoustic data as new tools for a 3D vision of the abiotic and biotic components of marine ecosystem and their interactions, in 2013 IEEE/OES Acoustics in Underwater Geosciences Symposium, RIO Acoustics, https://doi.org/10.1109/RIOAcoustics.2013.6683995, 2013.

Bianchi, D., Stock, C., Galbraith, E. D., and Sarmiento, J. L.: Diel vertical migration: Ecological controls and impacts on the biological pump in a one-dimensional ocean model, Global Biogeochem. Cy., 27, 478-491, https://doi.org/10.1002/gbc.20031, 2013.

Boersch-Supan, P. H., Rogers, A. D., and Brierley, A. S.: The distribution of pelagic sound scattering layers across the southwest Indian Ocean, Deep-Sea Res. Pt. II., 136, 108-121, https://doi.org/10.1016/j.dsr2.2015.06.023, 2017.

Brehmer, P., Georgakarakos, S., Josse, E., Trygonis, V., and Dalen, J.: Adaptation of fisheries sonar for monitoring schools of large pelagic fish: dependence of schooling behaviour on fish finding efficiency, Aquat. Living Resour., 20, 377-384, https://doi.org/10.1051/alr:2008016, 2007.

Brehmer, P., Sarré, A., Guennégan, Y., and Guillard, J.: Vessel Avoidance Response: A Complex Tradeoff Between Fish Multisensory Integration and Environmental Variables, Rev. Fish. Sci. Aquac., 27, 380-391, https://doi.org/10.1080/23308249.2019.1601157, 2019.

Brehmer, P. A. J.-P.: Fisheries Acoustics: Theory and Practice, 2nd edn, Fish Fish., 7, 227-228, https://doi.org/10.1111/j.14672979.2006.00220.x, 2006.

Breitburg, D.: Effects of hypoxia, and the balance between hypoxia and enrichment, on coastal fishes and fisheries, Estuaries, 25, 767-781, https://doi.org/10.1007/BF02804904, 2002.

Breitburg, D. L.: Behavioral response of fish larvae to low dissolved oxygen concentrations in a stratified water column, Mar. Biol., 120, 615-625, https://doi.org/10.1007/BF00350083, 1994.

Brochier, T., Auger, P.-A., Pecquerie, L., Machu, E., Capet, X., Thiaw, M., Mbaye, B. C., Braham, C.-B., Ettahiri, O., Charouki, N., Sène, O. N., Werner, F., and Brehmer, P.: Complex small pelagic fish population patterns arising from individual behavioral responses to their environment, Prog. Oceanogr., 164, 12 27, https://doi.org/10.1016/j.pocean.2018.03.011, 2018.

Brownrigg, R.: Package "maps", available at: http://cran.r-project. org/web/packages/maps/, last access: 1 April 2017.

Capet, X., Estrade, P., Machu, E., Ndoye, S., Grelet, J., Lazar, A., Marié, L., Dausse, D., and Brehmer, P.: On the Dynamics of the Southern Senegal Upwelling Center: Observed Variability from Synoptic to Superinertial Scales, J. Phys. Oceanogr., 47, 155180, https://doi.org/10.1175/JPO-D-15-0247.1, 2016.

Cascão, I., Domokos, R., Lammers, M. O., Marques, V., Domínguez, R., Santos, R. S., and Silva, M. A.: Persistent Enhancement of Micronekton Backscatter at the Summits of Seamounts in the Azores, Front. Mar. Sci., 4, 25, https://doi.org/10.3389/fmars.2017.00025, 2017.

Chessel, D., Dufour, A.-B., Dray, S., Jombart, T., Lobry, J. R., Ollier, S., and Thioulouse, J.: ade4: Analysis of Ecological Data: Exploratory and Euclidean Methods in Environmental Sciences, available at: https://cran.r-project.org/web/packages/ade4/index. html (last access: 12 February 2018), 2013.

Clark, C. W. and Levy, D. A.: Diel Vertical Migrations by Juvenile Sockeye Salmon and the Antipredation Window, Am. Nat., 131, 271-290, https://doi.org/10.1086/284789, 1988.

Coyle, K. O. and Cooney, R. T.: Water column sound scattering and hydrography around the Pribilof Islands, Bering Sea, Cont. Shelf Res., 13, 803-827, https://doi.org/10.1016/02784343(93)90028-V, 1993.

Cushing, D.: The vertical migration of planktonic Crustacea, Biol. Rev., 26, 158-192, 1951.

Davison, P. C., Koslow, J. A., and Kloser, R. J.: Acoustic biomass estimation of mesopelagic fish: backscattering from individuals, populations, and communities, ICES J. Mar. Sci., 72, 1413-1424, https://doi.org/10.1093/icesjms/fsv023, 2015.

Dekshenieks, M., Donaghay, P., Sullivan, J., Rines, J., Osborn, T., and Twardowski, M.: Temporal and spatial occurrence of thin phytoplankton layers in relation to physical processes, Mar. Ecol. Prog. Ser., 223, 61-71, https://doi.org/10.3354/meps223061, 2001.

Demarcq, H. and Faure, V.: Coastal upwelling and associated retention indices derived from satellite SST. Application to Octopus vulgaris recruitment, Oceanol. Acta, 23, 391-408, https://doi.org/10.1016/S0399-1784(00)01113-0, 2000.

Diankha, O., Ba, A., Brehmer, P., Brochier, T., Sow, B. A., Thiaw, M., Gaye, A. T., Ngom, F., and Demarcq, H.: Contrasted optimal environmental windows for both sardinella species in Senegalese waters, Fish. Oceanogr., 27, 351-365, https://doi.org/10.1111/fog.12257, 2018.

Donaldson, H. A.: Sound scattering by marine organisms in the northeastern Pacific Ocean, Oregon State Univ., available at: https://ir.library.oregonstate.edu/concern/graduate_thesis_or_ dissertations/cf95jd98h (last access: 6 December 2018), 1967.

Emerson, S., Stump, C., and Nicholson, D.: Net biological oxygen production in the ocean: Remote in situ measurements of $\mathrm{O}_{2}$ and $\mathrm{N}_{2}$ in surface waters, Global Biogeochem. Cy., 22, GB3023, https://doi.org/10.1029/2007GB003095, 2008.

Estrade, P., Marchesiello, P., De Verdière, A. C., and Roy, C.: Cross-shelf structure of coastal upwelling: A two - dimensional extension of Ekman's theory and a mechanism for inner shelf upwelling shut down, J. Mar. Res., 66, 589-616, https://doi.org/10.1357/002224008787536790, 2008.

Evans, R. A. and Hopkins, C. C. E.: Distribution and standing stock of zooplankton sound-scattering layers along the north Norwegian coast in February-March, 1978, Sarsia, 66, 147-160, https://doi.org/10.1080/00364827.1981.10414532, 1981.

Fässler, S. M. M., Fernandes, P. G., Semple, S. I. K., and Brierley, A. S.: Depth-dependent swimbladder compression in herring Clupea harengus observed using magnetic resonance imaging, J. Fish Biol., 74, 296-303, 2009.

Foote, K. G.: Calibration of acoustic instruments for fish density estimation: a practical guide, ICES Coop Res. Rep., 144, 1-69, 1987.

Fortier, L. and Harris, R.: Optimal foraging and density-dependent competition in marine fish larvae, Mar. Ecol. Prog. Ser., 51, 1933, https://doi.org/10.3354/meps051019, 1989.

Gausset, M. and Turrel, W. R.: Deep sound scattering layers in the Faroe Shetland channel., Scientific Report, FRS Marine Lab- 
oratory, Aberdeen, available at: http://www.gov.scot/Uploads/ Documents/IR1701.pdf (last access: 3 June 2017), 2001.

Godø, O. R., Patel, R., and Pedersen, G.: Diel migration and swimbladder resonance of small fish: some implications for analyses of multifrequency echo data, ICES J. Mar. Sci., 66, 1143-1148, https://doi.org/10.1093/icesjms/fsp098, 2009.

Gómez-Gutiérrez, J., González-Chávez, G., Robinson, C., and Arenas-Fuentes, V.: Latitudinal changes of euphausiid assemblages related to dynamics of the scattering layer along Baja California, October 1994, Sci. Mar., 63, 79-91, 1999.

Gray, C.: Do Thermoclines Explain the Vertical Distributions of Larval Fishes in the Dynamic Coastal Waters of South-eastern Australia?, Mar. Freshw. Res., 47, 183-190, https://doi.org/10.1071/MF9960183, 1996.

Gray, C. A. and Kingsford, M. J.: Variability in thermocline depth and strength, and relationships with vertical distributions of fish larvae and mesozooplankton in dynamic coastal waters, Mar. Ecol. Prog. Ser., 247, 211-224, https://doi.org/10.3354/meps247211, 2003.

Haney, J. F.: Diel Patterns of Zooplankton Behavior, B. Mar. Sci., 43, 583-603, 1988.

Hazen, E. L. and Johnston, D. W.: Meridional patterns in the deep scattering layers and top predator distribution in the central equatorial Pacific, Fish. Oceanogr., 19, 427-433, https://doi.org/10.1111/j.1365-2419.2010.00561.x, 2010.

Hidaka, K., Kawaguchi, K., Murakami, M., and Takahashi, M.: Downward transport of organic carbon by diel migratory micronekton in the western equatorial Pacific: its quantitative and qualitative importance, Deep-Sea Res. Pt. I, 48, 1923-1939, https://doi.org/10.1016/S0967-0637(01)00003-6, 2001.

Holliday, D. V., Greenlaw, C. F., and Donaghay, P. L.: Acoustic scattering in the coastal ocean at Monterey Bay, CA, USA: Fine-scale vertical structures, Cont. Shelf Res., 30, 81-103, https://doi.org/10.1016/j.csr.2009.08.019, 2010.

Jacox, M. G., Edwards, C. A., Hazen, E. L., and Bograd, S. J.: Coastal Upwelling Revisited: Ekman, Bakun, and Improved Upwelling Indices for the U.S. West Coast, J. Geophys. Res.-Oceans, 123, 7332-7350, https://doi.org/10.1029/2018JC014187, 2018.

JPL OurOcean Project: GHRSST Level 4 G1SST Global Foundation Sea Surface Temperature Analysis. Ver. 1. PO.DAAC, CA, USA, https://doi.org/10.5067/ghg1s-4fp01, 2010.

Kelley, D.: oce: Analysis of Oceanographic Data, available at: https: //cran.r-project.org/web/packages/oce/ (last access: 14 February 2018), 2015.

Kloser, R. J., Ryan, T., Sakov, P., Williams, A., and Koslow, J. A.: Species identification in deep water using multiple acoustic frequencies, Can. J. Fish. Aquat. Sci., 59, 1065-1077, https://doi.org/10.1139/f02-076, 2002.

Lampert, W.: The Adaptive Significance of Diel Vertical Migration of Zooplankton, Funct. Ecol., 3, 21-27, https://doi.org/10.2307/2389671, 1989.

Lee, H., Cho, S., Kim, W., and Kang, D.: The diel vertical migration of the sound-scattering layer in the Yellow Sea Bottom Cold Water of the southeastern Yellow sea: focus on its relationship with a temperature structure, Acta Oceanol. Sin., 32, 44-49, https://doi.org/10.1007/s13131-013-0351-z, 2013.

Lee, H., La, H. S., Kang, D., and Lee, S.: Vertical distribution of the sound-scattering layer in the Amundsen Sea, Antarctica, Po- lar Sci., 15, 55-61, https://doi.org/10.1016/j.polar.2017.12.003, 2018.

Lehodey, P., Conchon, A., Senina, I., Domokos, R., Calmettes, B., Jouanno, J., Hernandez, O., and Kloser, R.: Optimization of a micronekton model with acoustic data, ICES J. Mar. Sci., 72, 1399-1412, https://doi.org/10.1093/icesjms/fsu233, 2015.

Machu, E., Capet, X., Estrade, P. A., Ndoye, S., Brajard, J., Baurand, F., Auger, P.-A., Lazar, A., and Brehmer, P.: First Evidence of Anoxia and Nitrogen Loss in the Southern Canary Upwelling System, Geophys. Res. Lett., 46, 2619-2627, https://doi.org/10.1029/2018GL079622, 2019.

MacLennan, D. N., Fernandes, P. G., and Dalen, J.: A consistent approach to definitions and symbols in fisheries acoustics, ICES J. Mar. Sci., 59, 365-369, https://doi.org/10.1006/jmsc.2001.1158, 2002.

Maechler, M., Rousseeuw, P., Struyf, A., Hubert, M., and Hornik, K.: Package "cluster", Version, 1, 6-7, 2014.

Marchal, E., Gerlotto, F., and Stéquert, B.: On the relationship between scattering layer, thermal structure and tuna abundance in the eastern Atlantic equatorial current system, Oceanol. Acta, 16, 261-272, 1993.

Mbaye, B. C., Brochier, T., Echevin, V., Lazar, A., Lévy, M., Mason, E., Gaye, A. T., and Machu, E.: Do Sardinella aurita spawning seasons match local retention patterns in the SenegaleseMauritanian upwelling region?, Fish. Oceanogr., 24, 69-89, https://doi.org/10.1111/fog.12094, 2015.

Meester, L. D.: Diel Vertical Migration, in Encyclopedia of Inland Waters, edited by: Likens, G. E., Academic Press, Oxford, 651658, 2009.

Ndour, I., Berraho, A., Fall, M., Ettahiri, O., and Sambe, B.: Composition, distribution and abundance of zooplankton and ichthyoplankton along the Senegal-Guinea maritime zone (West Africa), Egypt. J. Aquat. Res., 44, 109-124, https://doi.org/10.1016/j.ejar.2018.04.001, 2018.

Ndoye, S., Capet, X., Estrade, P., Sow, B., Dagorne, D., Lazar, A., Gaye, A., and Brehmer, P.: SST patterns and dynamics of the southern Senegal-Gambia upwelling center, J. Geophys. Res.Oceans, 119, 8315-8335, https://doi.org/10.1002/2014jc010242, 2014.

Ndoye, S., Capet, X., Estrade, P., Sow, B., Machu, E., Brochier, T., Döring, J., and Brehmer, P.: Dynamics of a "lowenrichment high-retention" upwelling center over the southern Senegal shelf, Geophys. Res. Lett., 44, 5034-5043, https://doi.org/10.1002/2017GL072789, 2017.

Netburn, A. N. and Koslow, J. A.: Dissolved oxygen as a constraint on daytime deep scattering layer depth in the southern California current ecosystem, Deep-Sea Res. Pt. I, 104, 149-158, https://doi.org/10.1016/j.dsr.2015.06.006, 2015.

Ohman, M. D., Frost, B. W., and Cohen, E. B.: Reverse Diel Vertical Migration: An Escape from Invertebrate Predators, Science, 220, 1404-1407, https://doi.org/10.1126/science.220.4604.1404, 1983.

Olla, B. and Davis, M.: Effects of physical factors on the vertical distribution of larval walleye pollock Theragra chalcogramma under controlled laboratory conditions, Mar. Ecol. Prog. Ser., 63, 105-112, https://doi.org/10.3354/meps063105, 1990.

Perrot, Y., Brehmer, P., Habasque, J., Roudaut, G., Behagle, N., Sarré, A., and Lebourges-Dhaussy, A.: Matecho: An OpenSource Tool for Processing Fisheries Acoustics Data, Acoust. 
Aust., 46, 241-248, https://doi.org/10.1007/s40857-018-0135-x, 2018.

R Core Team: R: a language and environment for statistical computing, R Foundation for Statistical Computing, Vienna, Austria, available at: https://www.R-project.org/ (last access: 20 December 2018), 2016.

Rebert, J. P.: Hydrologie et dynamique des eaux du plateau continental sénégalais, Doc. Scient, CRODT, Sénégal, available at: http://horizon.documentation.ird.fr/exl-doc/pleins_textes/ divers11-12/17490.pdf (last access: 3 June 2017), 1983.

Rodrigues, E., Kiko, R., Brehmer, P., Machu, E., Silva, O., and ICAWA?: International Conference AWA, 3., Dakar (SEN), 2016/12/13-15: Analysis of zooplankton samples from AWA scientific research on board of R/V Thalassa 2014 using the zooscan approach [résumé], in International conference ICAWA 2016: extended book of abstract: the AWA project: ecosystem approach to the management of fisheries and the marine environment in West African waters, edited by: Brehmer, P., Ba, B., and Kraus, G., 46-47, SRFC/CSRP, Dakar, available at: http://www.documentation.ird.fr/hor/fdi:010072113 (last access: 16 January 2019), 2017.

Rojas, P. M. and Landaeta, M. F.: Fish larvae retention linked to abrupt bathymetry at Mejillones Bay (northern Chile) during coastal upwelling events, Lat. Am. J. Aquat. Res., 42, 989-1008, https://doi.org/10.3856/vol42-issue5-fulltext-6, 2014.

Röpke, A.: Do larvae of mesopelagic fishes in the Arabian Sea adjust their vertical distribution to physical and biological gradients?, Mar. Ecol. Prog. Ser., 101, 223-235, https://doi.org/10.3354/meps101223, 1993.

Roy, C.: An upwelling-induced retention area off Senegal: a mechanism to link upwelling and retention processes, South Afr. J. Mar. Sci., 19, 89-98, https://doi.org/10.2989/025776198784126881, 1998.

Sánchez-Velasco, L., Jimenez Rosenberg, S., and Lavín, M.: Vertical Distribution of Fish Larvae and Its Relation to Water Column Structure in the Southwestern Gulf of California1, Pac. Sci., 61, 533-548, https://doi.org/10.2984/15346188(2007)61[533:VDOFLA]2.0.CO;2, 2007.

Saunders, R. A., Fielding, S., Thorpe, S. E., and Tarling, G. A.: School characteristics of mesopelagic fish at South Georgia, Deep-Sea Res., 81, 62-77, 2013.

Sengupta, A., Carrara, F., and Stocker, R.: Phytoplankton can actively diversify their migration strategy in response to turbulent cues, Nature, 543, 555-558, https://doi.org/10.1038/nature21415, 2017.

Simmonds, J. and MacLennan, D.: Fisheries Acoustics: Theory and Practice, 2nd edn., Blackwell Publishing Ltd, Oxford, 2005a.

Simmonds, J. and MacLennan, D. N. (Eds.): Fisheries Acoustics: Theory and Practice, in: Fisheries Acoustics, i-xvii, Blackwell Publishing Ltd., 2005b.

Steele, J. H., Collie, J. S., Bisagni, J. J., Gifford, D. J., Fogarty, M. J., Link, J. S., Sullivan, B. K., Sieracki, M. E., Beet, A. R., and Mountain, D. G.: Balancing end-to-end budgets of the Georges Bank ecosystem, Prog. Oceanogr., 74, 423-448, 2007.
Stranne, C., Mayer, L., Jakobsson, M., Weidner, E., Jerram, K., Weber, T. C., Anderson, L. G., Nilsson, J., Björk, G., and Gårdfeldt, K.: Acoustic mapping of mixed layer depth, Ocean Sci., 14, 503514, https://doi.org/10.5194/os-14-503-2018, 2018.

Suh, H.-L. and Yu, O.-H.: Diel Horizontal Migration of Planktonic Copepods in the Surf Zone of Yongil Bay, Korea, Korean J. Fish. Aquat. Sci., 29, 527-536, 1996.

Teisson, C.: Le phénomène d'upwelling le long des côtes du Sénégal?: caractéristiques physiques et modélisation, Doc. Scient, CRODT, Dakar, available at: http://www.documentation.ird.fr/ hor/fdi:15418 (last access: 23 January 2018), 1983.

Thiaw, M., Auger, P.-A., Ngom, F., Brochier, T., Faye, S., Diankha, O., and Brehmer, P.: Effect of environmental conditions on the seasonal and inter-annual variability of small pelagic fish abundance off North-West Africa: The case of both Senegalese sardinella, Fish. Oceanogr., 26, 583-601, https://doi.org/10.1111/fog.12218, 2017.

Tiedemann, M. and Brehmer, P.: Larval fish assemblages across an upwelling front: Indication for active and passive retention, Estuar. Coast. Shelf S., 187, 118-133, https://doi.org/10.1016/j.ecss.2016.12.015, 2017.

Torgersen, T., Kaartvedt, S., Melle, W., and Knutsen, T.: Large scale distrlbution of acoustical scattering layers at the Norwegian continental shelf and the Eastern Norwegian Sea, Sarsia, 82, 87-96, 1997.

Touré, D.: Variation quantitative du zooplancton dans la région du Cap- Vert de septembre 1970 à août 1971, Doc. Scient., CRODT, Dakar, Sénégal, 1971.

Urmy, S. S. and Horne, J. K.: Multi-scale responses of scattering layers to environmental variability in Monterey Bay, California, Deep-Sea Res. Pt. I, 113, 22-32, https://doi.org/10.1016/j.dsr.2016.04.004, 2016.

Ward, J. H.: Hierarchical Grouping to Optimize an Objective Function, J. Am. Stat. Assoc., 58, 236-244, https://doi.org/10.1080/01621459.1963.10500845, 1963.

White, M. D.: Horizontal distribution of pelagic zooplankton in relation to predation gradients, Ecography, 21, 44-62, https://doi.org/10.1111/j.1600-0587.1998.tb00393.x, 1998.

Wilcox, R.: Chapter 12 - ANCOVA, in Introduction to Robust Estimation and Hypothesis Testing (Fourth Edition), edited by: Wilcox, R., 693-740, Academic Press, 2017.

Yasuma, H., Sawada, K., Ohshima, T., Miyashita, K., and Aoki, I.: Target strength of mesopelagic lanternfishes (family Myctophidae) based on swimbladder morphology, ICES J. Mar. Sci., 60, 584-591, https://doi.org/10.1016/S1054-3139(03)00058-4, 2003.

Yoon, W., Nival, P., Choe, S., Picheral, M., and Gorsky, G.: Vertical distribution and nutritional behaviour of Cyclothone braueri, Nematoscelis megalops, Meganyctiphanes norvegica and Salpa fusiformis in the NW Mediterranean mesopelagic zone, ICES CM F, 1-28, 2007. 